\title{
QUALIDADE, DESEMPENHO OPERACIONAL E CUSTO DE PLANTIOS, MANUAL E MECANIZADO, DE Eucalyptus grandis, IMPLANTADOS COM CULTIVO MÍNIMO DO SOLO
}

\section{VITOR AUGUSTO GRANER FESSEL}

\author{
Dissertação apresentada à Escola Superior de \\ Agricultura "Luiz de Queiroz", Universidade de São \\ Paulo, para obtenção do título de Mestre em Ciências, \\ Área de Concentração: Recursos Florestais.
}

PIRACICABA

Estado de São Paulo - Brasil

Maio - 2003 


\title{
QUALIDADE, DESEMPENHO OPERACIONAL E CUSTO DE PLANTIOS, MANUAL E MECANIZADO, DE Eucalyptus grandis, IMPLANTADOS COM CULTIVO MÍNIMO DO SOLO
}

\section{VITOR AUGUSTO GRANER FESSEL}

Engenheiro Florestal

\author{
Orientador: Prof. Dr. MARCOS MILAN
}

\footnotetext{
Dissertação apresentada à Escola Superior de Agricultura "Luiz de Queiroz", Universidade de São Paulo, para obtenção do título de Mestre em Ciências, Área de Concentração: Recursos Florestais.
}

PIRACICABA

Estado de São Paulo - Brasil

Maio - 2003 
Dados Internacionais de Catalogação na Publicação (CIP)

DIVISÃO DE BIBLIOTECA E DOCUMENTAÇÃO - ESALQ/USP

\section{Fessel, VitorAugusto Graner}

Qualidade, desempenho operacional e custo de plantios, manuale mecanizado, de Eucalyptus grand is, implantados com cultivo mínimo do solo / VitorAugusto GranerFessel. - - Piracicaba, 2003.

$88 \mathrm{p}$.

Dissertação (mestrado) - - Escola Superior de Agricultura Luiz de Queiroz, 2003.

Bibliografia.

1. Cultivo mínimo 2. Custo operacional 3. Desemp enho operac ional 4.

Eucalipto 5. Plantio 6. Preparo do solo I. Título

CDD 634.9734

"Permitida a cópia total ou parcial deste documento, desde que citada a fonte - $\mathrm{O}$ autor" 
Aos meus pais, José Vicente e Maria Cecília, ao meu irmão Paulo Afonso, à minha tia Maria de Lourdes (in memorian) e àminha esposa Conceição Aparecida, dedico. Ao escritor Millôr Fernandes que uma vez afirmou: "procure a causa sempre perto dos efeitos; meu tio me dizia que é totalmente impossível uma jaca cair a duzentos metros da jaqueira." 


\section{AGRADECIMENTOS}

Aos professores do Programa de Pós-graduação em Recursos Florestais do Departamento de Ciências Florestais (LCF) e da Escola Superior de Agricultura "Luiz de Queiroz" (ESALQ), que me acompanharam em minha formação acadêmica. Aos funcionários do LCF e da ESALQ que me apoiaram.

Ao prof. Dr. Marcos Milan pela orientação recebida durante o mestrado, pelo incentivo àmudança de postura profissional através dos conceitos da qualidade total e pelo apoio nos momentos difíceis da execução do trabalho.

Aos colaboradores da empresa Ripasa S/A Celulose e Papel, em especial aos engenheiros florestais Richard Respondovesk e Vanderson Fernandes, bem como aos técnicos que trabalham na fazenda Fortaleza, pelo apoio e pelas sugestões àpesquisa.

Aos engenheiros e técnicos da empresa Metasa S.A., Divisão de Implementos Agrícolas, em especial ao engenheiro Paulo Roberto Montagner, pela assistência técnica prestada durante o desenvolvimento e a avaliação da transplantadora de mudas MTM-1000.

Ao Instituto de Pesquisas e Estudos Florestais (IPEF), em especial ao Programa de Silvicultura e Manejo Florestal, pelo apoio logístico. À empresa Jari Celulose S.A. pelo apoio durante a execução do trabalho. Aos colegas de profissão que, de alguma forma, contribuíram para a realização da dissertação. 


\section{SUMÁRIO}

Página

LISTA DE FIGURAS ............................................................................... viii

LISTA DE TABELAS …....................................................................... xi

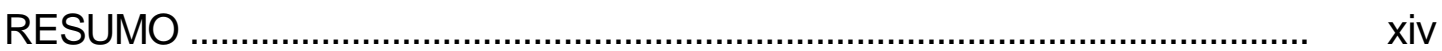

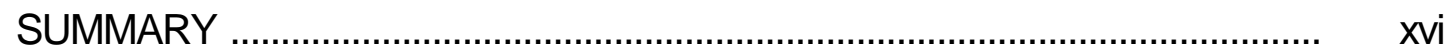

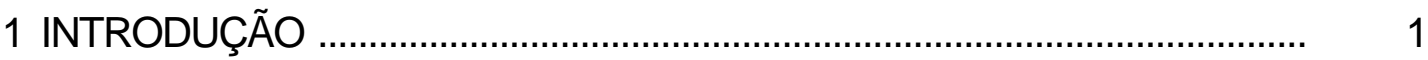

2 REVISÃO DA LITERATURA …........................................................... 3

2.1 Fatores que influenciam a operação de plantio ...................................... 3

2.1.1 Colheita mecanizada da madeira ......................................................... 3

2.1.2 Preparo mecanizado do solo ............................................................... 4

2.1.3 Qualidade das mudas ....................................................................... 7

2.1.4 Sistemas de plantio ........................................................................... 9

2.2 Qualidade total .............................................................................. 16

2.2.1 Conceitos básicos da qualidade total .................................................. 16

2.2.2 Avaliação de processos e produtos pela qualidade total ..................... 18

2.2.3 Qualidade total nas operações agrícolas e florestais .......................... 23

2.3 Desempenho operacional e custo das máquinas agrícolas ................... $\quad 25$

3 MATERIAL E MÉTODOS ....................................................................... 28

3.1 Descrição das atividades de preparo do solo e de plantio ..................... 29

3.1.1 Preparo mecanizado do solo .................................................................. 29

3.1.2 Seleção das mudas para o plantio ......................................................... 29

3.1.3 Sistemas de plantio .......................................................................... $\quad 30$

3.2 Amostragem e instalação das parcelas ............................................... 31

3.3 Itens de verificação do preparo do solo que influenciam o plantio .......... 32 
3.3.1 Profundidade do sulco do preparo mecanizado do solo

3.3.2 Diâmetro dos torrões sobre a linha central do sulco

3.3.3 Volume cilíndrico dos galhos de madeira sobre a faixa de sulcamento

3.4 Itens de controle dos sistemas de plantio 38

3.5 Ferramentas da qualidade total utilizadas 39

3.5.1 Gráfico de controle da média 40

3.5.2 Gráfico de controle do desvio-padrão ................................................ 40

3.5.3 Gráfico de controle da amplitude ....................................................... 41

3.5.4 Gráfico de controle do número total de defeitos por unidade .............. 41

3.6 Análises estatísticas dos resultados ........................................................... 42

3.7 Estimativas operacionais dos sistemas de plantio ................................. 42

3.7.1 Desempenho operacional .................................................................. 42

3.7.2 Custo operacional .............................................................................. 44

3.7.2.1 Custo fixo horário das máquinas ........................................................ 44

3.7.2.2 Custo variável horário das máquinas ............................................... 47

3.7.2.3 Custo variável horário da mão-de-obra ................................................ 48

3.7.2.4 Custo horário total dos sistemas de plantio ......................................... 49

3.7.2.5 Custo operacional dos sistemas de plantio ....................................... 49

4 RESULTADOS E DISCUSSÃO .............................................................. 50

4.1 Itens de verificação do preparo do solo que influenciaram o plantio ...... 50

4.1.1 Profundidade do sulco do preparo mecanizado do solo ..................... 50

4.1.2 Diâmetro dos torrões sobre a linha central do sulco ........................... 53

4.1.3 Volume cilíndrico dos galhos de madeira sobre a faixa de sulcamento ......................................................................................... 53

4.1.4 Análise conjunta dos itens de verificação do preparo do solo ............. 54

4.2 Itens de controle dos sistemas de plantio ................................................ 55

4.2.1 Distância entre plantas ..................................................................... 55

4.2.2 Defeitos do plantio ............................................................................. 58

4.2.3 Crescimento inicial e sobrevivência das plantas ................................ 61 
4.3 Relações de causa e efeito nos sistemas de plantio

4.4 Estimativas do desempenho e custo operacionais dos sistemas de plantio

5 CONCLUSÕES 


\section{LISTA DE FIGURAS}

Página

1 Ferramentas para o plantio manual de eucalipto: a) chucho; b) transplantadora de acionamento manual

2 Transplantadora de acionamento mecânico da marca Arador

3 Dimensões da qualidade total

4 Ciclo PDCA

5 Distribuição dos valores em um processo sob controle

6 Diagrama 6M

7 Gráfico de controle: os pontos do gráfico representam a variação da qualidade em amostras seqüenciais

8 Sistemas de plantio que foram estudados: a) manual; b) mecanizado

9 Esquema de malha das parcelas mostrando as vinte e cinco linhas de preparo de solo e plantio (na horizontal) e os quinze pontos amostrais por linha (na vertical) 
10 Esquemas da amostragem da resistência do solo à penetração, no sulco, após o preparo do solo: a) locações dos quinze transectos em uma linha de preparo do solo; e b) transecto mostrando $o$ penetrômetro e os sete pontos amostrais $(E=$ a esquerda do centro do sulco; $D=$ a direita do centro do sulco)

11 Esquemas da amostragem do diâmetro dos torrões, na projeção do centro do sulco, após o preparo do solo: a) locações dos pontos de amostragem com a haste em uma linha de preparo do solo; e b) amostra mostrando a haste, os torrões e o sulco de preparo do solo

12 Esquema mostrando a haste e os pontos de amostragem dos torrões (em vermelho). No exemplo, somente seriam medidos os torrões dos pontos a, c e d, pois foram os que coincidiram com as marcas vermelhas da haste

13 Esquemas da amostragem dos galhos sobre a faixa de sulcamento, após o preparo do solo: a) locações das áreas amostrais em uma linha de preparo do solo; e b) área amostral mostrando os galhos e o sulco de preparo do solo

14 Variação média do sulco de preparo do solo em cinco linhas de trabalho ( $L 1$ a $L 5)$ e em quinze transectos consecutivos

15 Gráficos de controle da média para a profundidade do sulco de preparo do solo (LIC = Limite Inferior de Controle; LSC = Limite Superior de Controle; LE = Linha de Especificação) 
16 Gráficos de controle para o diâmetro do torrão: a) média; b) amplitude (LSC = Limite Superior de Controle; LIC = Limite Inferior de Controle)

17 Gráficos de controle para o volume cilíndrico dos galhos: a) média; b) amplitude (LSC = Limite Superior de Controle)

18 Histogramas de distribuição da distância entre plantas: a) sistema manual; b) sistema mecanizado (LE = Linha de Especificação)

19 Gráficos de controle para a distância entre plantas: a) média para o sistema manual; b) desvio-padrão para o sistema manual; c) média para o sistema mecanizado; d) desviopadrão para o sistema mecanizado (LSC = Limite Superior de Controle; LIC = Limite Inferior de Controle; LE = Linha de Especificação)

20 Gráficos de controle do número de defeitos por muda efetivamente plantada: a) sistema manual; b) sistema mecanizado (LSC = Limite Superior de Controle)

21 Gráficos de Pareto para os defeitos do plantio: a) sistema manual; b) sistema mecanizado ( $\mathrm{CE}=$ muda com colo encoberto pelo solo; FCS = muda fora do centro do sulco; DF = muda com danos nas folhas; DP $=$ muda com danos no ponteiro; $\mathrm{PI}=$ muda plantada inclinada; NF = muda não firme; $\mathrm{NP}=$ muda não plantada; SE = muda com substrato exposto; Ent $=$ muda enterrada; Jog = muda jogada) 
22 Histogramas da altura inicial da parte aérea das mudas: a) sistema manual; b) sistema mecanizado (LIE = Limite Inferior de Especificação; LSE = Limite Superior de Especificação)

23 Histogramas da altura da parte aérea das mudas, após um mês de idade: a) sistema manual; b) sistema mecanizado

24 Diagrama 6M aplicado a operação de plantio das mudas

25 Distribuição dos tempos produtivos, acessórios (manobras) e auxiliares (regulagens, abastecimento de água para irrigação e carregamento das mudas) no sistema de plantio mecanizado 


\section{LISTA DE TABELAS}

Página

1 Teor de água dos solos após o preparo

2 Comparação das médias da distância entre plantas, entre os sistemas de plantio, pelo teste t não-pareado

3 Comparação das médias do número de defeitos por muda plantada, entre os sistemas, pelo teste t não-pareado

4 Comparação da presença ou ausência dos defeitos no plantio, entre os sistemas, pelo teste de qui-quadrado ( $\mathrm{CE}=$ muda com colo encoberto pelo solo; FCS = muda fora do centro do sulco; $D F=$ muda com danos nas folhas; $D P=$ muda com danos no ponteiro; $\mathrm{PI}=$ muda plantada inclinada; $\mathrm{NF}=$ muda não firme; $N P=$ muda não plantada; $S E=$ muda com substrato exposto; Ent = muda enterrada; Jog = muda jogada)

5 Comparação das médias da altura da parte aérea das mudas inicial e após um mês de idade, entre os sistemas de plantio, pelo teste t não-pareado

6 Comparação da sobrevivência ou não das mudas após um mês de idade, entre os sistemas de plantio, pelo teste de quiquadrado 
7 Composição do custo horário $\left(R \$ h^{-1}\right)$ dos sistemas de plantio (ASI = alojamentos, seguros e impostos; $\mathrm{RM}=$ reparos e manutenção)

8 Custo horário total $\left(\mathrm{R} \$ \mathrm{~h}^{-1}\right)$ dos sistemas de plantio .

9 Custo operacional $\left(\mathrm{R} \$ \mathrm{ha}^{-1}\right)$ dos sistema de plantio... 


\title{
QUALIDADE, DESEMPENHO OPERACIONAL E CUSTO DE PLANTIOS, MANUAL E MECANIZADO, DE Eucalyptus grandis, IMPLANTADOS COM CULTIVO MÍNIMO DO SOLO
}

\author{
Autor: VITOR AUGUSTO GRANER FESSEL \\ Orientador: Prof. Dr. MARCOS MILAN
}

\section{RESUMO}

O método de plantio manual de mudas de árvores é predominante no Brasil. Para a redução dos custos com mão-de-obra, aumento de produtividade e qualidade operacional, o plantio manual deve ser substituído total ou parcialmente por operações mecanizadas. Com esse enfoque foram avaliadas as atividades de plantios manual e mecanizado de eucaliptos, bem como de preparo mecanizado do solo, em área pertencente a uma empresa florestal. O plantio manual foi feito por onze trabalhadores rurais, com o uso da transplantadora de acionamento manual. $O$ plantio mecanizado foi realizado por uma máquina de transplantio de mudas, operada por um trabalhador rural e tracionada por um trator. $\mathrm{Na}$ área do estudo foram locadas duas parcelas amostrais, formando uma malha de setenta e cinco pontos amostrais para cada sistema de plantio. Os itens do preparo do solo avaliados foram a profundidade do sulco, o diâmetro dos torrões e o volume cilíndrico dos galhos de madeira sobre a faixa de sulcamento. $O$ itens dos sistemas de plantio avaliados foram a presença de defeitos da operação, a distância entre plantas, a altura da parte aérea das mudas e a sobrevivência das plantas após um mês de idade. As 
ferramentas da qualidade total utilizadas foram os histogramas, o diagrama de causa e efeito, os gráficos de Pareto e de controle. As análises estatísticas dos resultados foram feitas pelo teste t e pelo teste de qui-quadrado Para avaliar o desempenho operacional do sistema manual estimou-se somente a capacidade de campo operacional. No sistema mecanizado foram estimadas as capacidades de campo efetiva e operacional. Nos dois sistemas de plantio foram estimados também os custos horários e operacionais das máquinas e da mão-de-obra. Entre os sistemas de plantio, a distância entre plantas foi diferente estatisticamente, com melhor distribuição das mudas no sistema manual. O número de defeitos por muda plantada foi semelhante estatisticamente entre os sistemas de plantio. Os principais defeitos do sistema manual foram as mudas plantadas com colo encoberto pelo solo e as mudas plantadas fora do centro do sulco, os quais representaram $72,8 \%$ do total. No sistema mecanizado, esses defeitos, somados à mudas não plantadas e mudas não firmes, representaram $76,7 \%$ do total. A altura da parte aérea foi diferente estatisticamente, tanto no plantio como um mês após. A sobrevivência das mudas efetivamente plantadas, após um mês de idade, foi semelhante estatisticamente. Concluiu-se, assim, que a qualidade em ambos os sistemas de plantio não variaram dentro de padrões aceitáveis pela empresa florestal. $\mathrm{O}$ tempo produtivo do sistema de plantio mecanizado foi igual a $48,2 \%$, gerando uma capacidade de campo operacional $60,0 \%$ menor do que no sistema manual. Inferiu-se que o número médio de mudas plantadas por trabalhador por hora foi igual a 95 no sistema manual, enquanto que no sistema mecanizado foi igual a 205. O custo operacional estimado do sistema mecanizado foi $44,9 \%$ maior do que no sistema manual, fato devido a baixa capacidade de campo operacional observada no sistema mecanizado. 


\title{
QUALITY, OPERATIONAL PERFORMANCE AND COST OF Eucalyptus grandis HAND AND MACHINE PLANTING, IMPLEMENTED WITH MINIMAL TILLAGE
}

\author{
Author: VITOR AUGUSTO GRANER FESSEL \\ Adviser: Prof. Dr. MARCOS MILAN
}

\section{SUMMARY}

Hand planting of tree seedlings is the predominant method in Brazil. In order to reduce labor costs, increase productivity, and improve operational quality, hand planting should be totally or partially replaced by machine operations. Having this in mind, eucalyptus' hand and machine planting activities were assessed, as well as those of mechanical tillage, in an area belonging to a forestation company. Hand planting had been carried out by 11 rural workers by using a planting tube. Machine planting had been carried out by using a seedling transplant machine, which was operated by a rural worker and pulled by a tractor. In the study area, two sampling parts were allocated, forming a web with 75 sampling points for each planting system. Tillage items that were assessed included furrow depth, stone diameter, and the cylindrical volume of wood branches on the furrow belt. Planting system items that were assessed included the presence of operation defects, distance between plants, height of the top portion of the seedlings, and plant survival after one month of age. Total quality tools included histograms, cause and effect diagram, control graphs, and Pareto's graphs. Statistical analyses of the results were performed by using $t$ 
test and qui-square test. To evaluate hand planting system's operational performance, only the operational field capacity was estimated. As for the machine system, effective and operational field capacities were estimated. Labor and machine hourly costs, as well as the operational costs for both planting systems were assessed. When comparing planting systems, the distance between plants was statistically different, with hand planting system showing better seedling distribution. The number of defects per planted seedling was statistically similar for both planting systems. The major defects in the hand planting system were seedlings planted with soil-covered base and those planted out of the furrow center, which represented $72.8 \%$ of the total. With the machine system, these defects, in addition to non-planted and loose seedlings, represented $76.7 \%$ of the total. The height of the top portion was statistically different, both when planting and after one month. The survival of effectively planted seedlings after one month of age was statistically similar. Thus, we concluded that the quality of both planting systems did not vary within the standards that are acceptable for the forestation company. Machine planting system's productive time was $48.2 \%$, and generated an estimated operational field capacity $60.0 \%$ less to that for the hand planting system. The average number of planted seedlings per worker by hour was inferred to be equal to 95 in the hand planting system, whereas it was equal to 205 in the machine system. The operational cost for he machine system was estimated to be $44.9 \%$ greater to that for the hand planting system, which is due to the low operational field capacity observed in the machine system. 


\section{INTRODUÇÃO}

No ano de 2000, o setor florestal brasileiro gerou recursos da ordem de 21,0 bilhões de dólares, representando 4,0\% do Produto Interno Bruto (PIB) nacional. As exportações do setor acumularam 5,4 bilhões de dólares, equivalendo a $10,0 \%$ do total do país. Foram recolhidos 2,0 bilhões de dólares em impostos e mantidos 2,0 milhões de empregos diretos e indiretos. Nesse ano, as empresas de celulose e papel consumiram 17,4 milhões de toneladas de madeira, produzindo 7,4 milhões de toneladas de celulose e 7,1 milhões de toneladas de papel (Sociedade Brasileira de Silvicultura - SBS, 2002). Essas empresas plantaram 180,0 milhões de árvores, abrangendo uma área de 119,4 mil hectares. O gênero mais cultivado foi o Eucalyptus, ocupando 101,1 mil hectares, o que representou $84,7 \%$ de toda a área plantada (Associação Brasileira de Celulose e Papel - Bracelpa, 2001).

Para as empresas brasileiras atenderem a um incremento constante da demanda de celulose e papel e manterem a participação no mercado mundial, há necessidade de se ampliar a produção das fábricas e, conseqüentemente, da área atual de plantio de mudas de árvores por ano. $\mathrm{O}$ método de plantio manual ainda é predominante no Brasil e exige, segundo a "Oficina Internacional del Trabajo" (OIT, 1968), moderado esforço físico humano. Além disso, esse método de plantio representa 10,0\% do custo total da reforma de povoamentos florestais (Gonçalves et al., 2000). Para a redução desse custo e desse esforço físico humano, o plantio manual de mudas de 
eucaliptos deve ser substituído total ou parcialmente por operações mecanizadas.

A tomada de decisão para a seleção do sistema de plantio manual ou mecanizado é feita pela avaliação dos desempenhos operacional e econômico das atividades. Entretanto, a adoção do sistema de plantio não irá depender somente da capacidade operacional e ob custo, mas, também, da qualidade do plantio, o que determina se a operação está adequada ou não aos padrões recomendados pela empresa florestal.

Com esse enfoque, este estudo objetivou avaliar a qualidade, 0 desempenho operacional e o custo de sistemas de plantios manual e mecanizado de eucaliptos, em área implantada com cultivo mínimo do solo de uma empresa florestal privada do Estado de São Paulo.

As hipóteses do trabalho propostas para alcançar esses objetivos foram:

- A variação na qualidade das ativi dades de preparo mecanizado do solo e plantio estava dentro de padrões aceitáveis pela empresa florestal;

- A capacidade de campo operacional do sistema de plantio mecanizado era superior ao do manual;

- O sistema mecanizado realizava um plantio qualitativamente igual ao manual; e

- O custo operacional do sistema de plantio mecanizado era inferior ao do manual, para uma única jornada diária de trabalho de oito horas. 


\section{REVISÃO DA LITERATURA}

\subsection{Fatores que influenciam a operação de plantio}

\subsubsection{Colheita mecanizada da madeira}

A intensificação da mecanização das operações da colheita da madeira no início da década de 1990, no Brasil, gerou um aumento da preocupação com a compactação dos solos e com as novas dificuldades para o preparo em áreas de reforma florestal (Seixas, 2002; Seixas \& Oliveira Júnior, 2001).

A compactação pode ser definida como um novo arranjo e aproximação das partículas sólidas do solo, apresentando redução da macroporosidade e aumento da densidade do solo. Com isso, as taxas de infiltração de água são menores e mais lentas, a aeração é também menor e há maior resistência àelongação radicular das plantas (Seixas, 1988a).

Avaliando os efeitos da colheita mecanizada de eucalipto na compactação do solo, Dedecek \& Gava (1997) concluíram que as operações mecanizadas de colheita da madeira causam compactação no solo, sendo mais observada até $0,3 \mathrm{~m}$ de profundidade, com valores máximos entre $0,1 \mathrm{~m}$ e 0,2 $\mathrm{m}$ em solo argiloso e entre 0,2 $\mathrm{m}$ e 0,3 $\mathrm{m}$ em solo arenoso, provocando reduções de até dois terços na produtividade do eucalipto aos sete anos de idade. 
Os resíduos da colheita da madeira que permanecem como cobertura e proteção da superfície do terreno também dificultam as operações mecanizadas de preparo do solo e plantio. Comumente, essas operações têm que ser interrompidas para a retirada de galhos acumulados junto æ̀ máquinas (Seixas, 2002), o que pode provocar conseqüentemente, a diminuição da capacidade operacional e o aumento da variabilidade da qualidade das atividades.

Estudando diferentes métodos de plantio de Pinus taeda, Balensiefer (1978) concluiu que obstáculos como tocos e galhos provocam a redução da capacidade operacional das atividades de plantio e que perturbam mais a operação de plantio mecanizado do que a operação manual.

\subsubsection{Preparo mecanizado do solo}

Define-se preparo do solo como o rompimento periódico da massa contínua do solo, o qual pode ser realizado por inversão de camadas, por deslocamento lateral-horizontal, por desagregação subsuperficial ou por revolvimento rotativo. São usadas quatro máquinas básicas para obter cada um desses efeitos: arados para a inversão de camadas; grades para 0 deslocamento lateral-horizontal; subsoladores para a desagregação subsuperficial; e enxadas rotativas para o revolvimento do solo (Gamero \& Lanças, 1996). A subsolagem tem como função principal romper as camadas compactadas do solo, em profundidades maiores do que 0,40 m. Quando a desagregação do solo é superficial, o processo é denominado de escarificação, pois o preparo do solo feito pelos escarificadores é realizado até $0,35 \mathrm{~m}$ de profundidade (Silveira, 1988; Lanças, 2002). 
No setor florestal, desde o início da década de 1980, o preparo do solo para o plantio de eucalipto é considerado um fator primordial para o bom desenvolvimento das mudas e a uniformidade da produção do povoamento. Naquela década o cultivo do solo era intensivo, com amplo revolvimento das suas camadas superficiais e incorporação dos resíduos culturais, através do uso de arados e grades (Gonçalves et al., 2000).

Atualmente, o método de preparo do solo mais utilizado pelas empresas florestais, no Brasil, é o cultivo reduzido do solo (cultivo mínimo), o qual é realizado apenas na linha de plantio, trabalhando-se em uma largura e em uma profundidade menores que 0,5 m. Nesse sistema, a maior parte dos resíduos culturais são mantidos sobre a superfície do solo (Gonçalves et al., 2000). O cultivo mínimo é considerado um método conservacionista desde que se mantenha os resíduos culturais em, pelo menos, 30,0\% da superfície do solo ou em $1 \mathrm{t} \mathrm{ha}^{-1}$ ("American Society of Agricultural Engineering" - ASAE, 2001a; Brady \& Weil, 1999).

$\mathrm{Na}$ agricultura moderna, os subsoladores e escarificadores vem substituindo com grandes vantagens os arados e grades (Lanças, 2002). No preparo do solo para o plantio de eucalipto, no sistema de cultivo mínimo, os subsoladores são os principais implementos usados. Eles são equipados com uma barra porta-ferramentas, haste de aço plana e ponta, podendo ser de arrasto ou acoplados no sistema hidráulico dos tratores (Burla, 2001). As hastes possuem três formatos: reta, curva ou parabólica. Elas podem apresentar também aletas, nas suas pontas, com o objetivo de aumentar o volume do solo mobilizado.

As hastes dos subsoladores e escarificadores são cravadas no solo e provocam o seu rompimento para frente, para cima e para os lados, 
tridimensionalmente e em blocos. O solo não é cortado e sim rompido nas suas linhas de fraturas naturais ou através das interfaces dos seus agregados. Assim, a mobilização feita por esses equipamentos é menos agressiva do que aquelas nas quais as lâminas cortam o solo de forma indiscriminada e contínua, como nos arados e grades, destruindo sua estruturação original (Lanças, 2002). O tipo de haste mais usado no preparo do solo para florestas é a parabólica, pois exige menos força de tração, desde que o seu trecho curvo fique totalmente fora do solo, a fim de evitar a presença de componentes que forcem o subsolador para cima (Balastreire, 1990; Burla, 2001).

Em trabalho que avaliou a influência de diversos métodos de preparo do solo, em áreas com camada de impedimento, Suiter-Filho et al. (1980) concluíram que o uso das grades e dos subsoladores influenciaram favoravelmente, até os 14 meses de idade, o crescimento, a homogeneidade e a sobrevivência das mudas de eucalipto.

Comparando o processo de subsolagem e o de escarificação como preparo do solo para o plantio de mudas de eucalipto, Borssato et al. (1983) concluíram que o crescimento em altura das plantas, até os 18 meses de idade, responde prontamente a qualquer melhoria em preparo do solo e que a subsolagem ou a escarificação são práticas recomendáveis onde existam camadas de impedimento.

Estudando a mobilização do solo e o seu efeito sobre o crescimento inicial do eucalipto, em condições de cultivo mínimo, Bentivenha et al. (2000) verificaram maior mobilização em solo de textura arenosa, com uma haste subsoladora parabólica trabalhando a uma profundidade de 0,4 $\mathrm{m}$. Essa maior mobilização resultou em maior crescimento em diâmetro do colo e em altura das plantas, até os 11 meses de idade. 
Em trabalho sobre o planejamento da qualidade do preparo mecanizado do solo para a implantação de povoamentos de eucalipto, Barros (2001) concluiu que o solo não deve apresentar limitações físicas, deve possuir torrões uniformes e não deve apresentar cobertura vegetal que dificulte a mecanização das operações.

Smith (1962) afirmou que um outro objetivo do preparo do solo é facilitar a operação de plantio. A qualidade do preparo do solo provoca alterações nas operações de plantio, tanto na sua velocidade como na sua qualidade. Entretanto, o relacionamento dessas variáveis não é facilmente quantificável (Stjernberg, 1988a). Em estudo feito no Canadá, Stjernberg (1991) avaliou o desempenho operacional do plantio manual de mudas de árvores em áreas preparadas mecanicamente e não preparadas. $\mathrm{O}$ autor observou que a produtividade da operação de plantio, nas áreas preparadas, foi incrementada em mais de 50,0\% em relação æ̀ áreas não preparad as. Dessa maneira, concluiu que o preparo mecanizado do solo pode aumentar a produtividade dos trabalhadores que executam o plantio.

Em síntese, solos bem preparados apresentam condições físicas balanceadas, isto é, a disponibilidade da água, a aeração e a resistência mecânica do solo variam entre limites que proporcionam facilidade de manejo e boa produtividade (Letey, 1985).

\subsubsection{Qualidade das mudas}

A classificação de mudas pelo seu padrão de qualidade causa, após o seu plantio, aumento da percentagem de sobrevivência e diminuição da freqüência dos tratos culturais de manutenção dos povoamentos (Carneiro, 1983). 
Os parâmetros para a avaliação da qualidade das mudas, no viveiro e no campo, podem ser morfológicos, baseados nos seus aspectos fenotípicos, ou fisiológicos, baseados nas suas funções orgânicas (Carneiro, 1995). Schmidt-Vogt, citado por Carneiro (1995), classificou como parâmetros morfológicos que determinam a qualidades das mudas:

- Altura;

- Atributos de vigor: peso total da muda; peso da parte aérea; diâmetro do colo; e as relações peso total da muda pela altura da parte aérea, peso da parte aérea pela altura da parte aérea, diâmetro do colo pela altura da parte aérea, peso e/ou comprimento da parte aérea pela parte radicular;

- Capacidade de enraizamento: peso das raízes; comprimento das raízes; superfície ativa das raízes; freqüência de micorrizas nas raízes; percentagem de raízes; e a relação peso das raízes pela altura da parte aérea;

- Capacidade de assimilação: ramificação; formação de folhas ou acículas; e qualidade e quantidade de brotos;

- Comprimento de acículas; e comprimento de raízes.

Os parâmetros fisiológicos que determinam a qualidade das mudas são estimados pelo seu potencial hídrico, o seu estado nutricional e a ecofisiologia do seu sistema radicular. Entretanto, os parâmetros morfológicos como a altura, o diâmetro do colo, a maturação da parte aérea e 0 desenvolvimento do sistema radicular, por serem mais facilmente quantificáveis, são os mais usados (Carneiro, 1995).

Estudando a qualidade das mudas de eucalipto produzidas em blocos prensados e em "tubetes", Leles et al. (2000) usaram como parâmetros a altura da parte aérea, o diâmetro do colo, a área foliar, o peso de matéria seca do sistema radicular e o peso de matéria seca da parte aérea. 
Comparando o desenvolvimento das mudas selecionadas e não selecionadas de eucalipto, Mello et al. (1993) verificaram que o Diâmetro à Altura do Peito (DAP), a área basal e o volume cilíndrico, até os 26 meses de idade, foram superiores nas plantas que sofreram seleção. Entretanto, a altura e a percentagem de sobrevivência não foram influenciadas pela realização ou não da seleção das mudas.

Avaliando os efeitos da implantação de um sistema de controle de qualidade em dez operações da produção de mudas de eucalipto em uma empresa florestal, Trindade (1993) observou, após um ano, que houve um incremento de $24,3 \%$ no grau de qualidade das mudas.

\subsubsection{Sistemas de plantio}

Plantio é o trabalho de transplante das mudas do viveiro para o campo, podendo ser manual, semi-mecanizado ou mecanizado. A escolha do método está condicionada principalmente à topografia do terreno, àextensão da área de plantio e aos custos. Em terrenos com topografia acidentada, o método geralmente usado é o manual e em áreas planas, pode-se mecanizar o plantio. No Brasil, o sistema manual difundiurse como o principal método, mesmo em áreas planas, devido ao baixo custo da mão-de-obra (Simões, 1989). O plantio manual é realizado com uma ferramenta denominada de chucho (Figura 1a) e com a transplantadora de acionamento manual (Figura 1b) (Burla, 2001). 


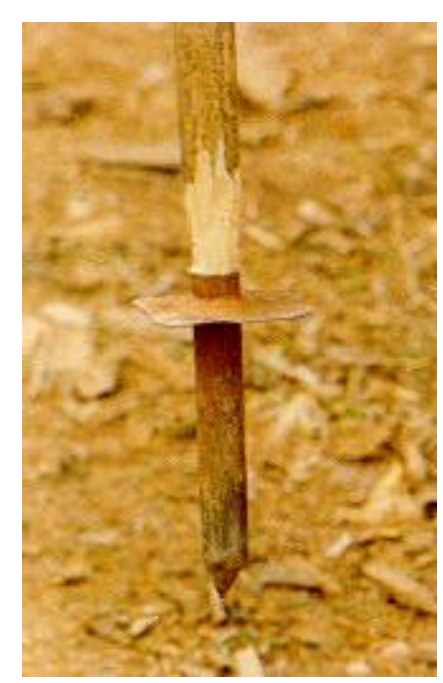

(a)

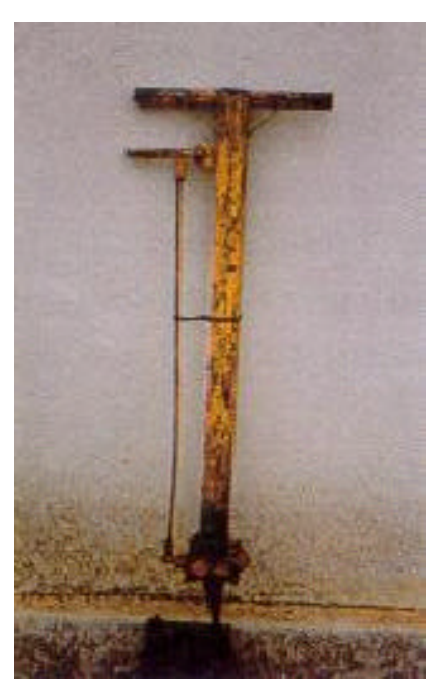

(b)

Figura 1 - Ferramentas para o plantio manual de eucalipto: a) chucho; b) transplantadora de acionamento manual (Burla, 2001).

O chucho é composto por uma haste de madeira ou aço com 0,85 a 1,22 m de comprimento, uma ponta para perfurar o solo e um limitador de profundidade. A transplantadora de acionamento manual é composta por um tubo oco de aço ou alumínio com 2,5 a 3,1 kg, comprimento entre 0,93 m e 0,95 $\mathrm{m}$, diâmetro interno entre $0,04 \mathrm{~m}$ e $0,07 \mathrm{~m}$, uma ponta com lâminas para perfurar o solo, uma alavanca que controla a abertura das lâminas e um limitador de profundidade (Stjernberg, 1988b).

Avaliando a produtividade dos trabalhadores rurais no plantio manual com P. taeda, Balensiefer (1978) observou que o número de mudas plantadas por pessoa foi, em média, 81 por hora.

Estudando as operações de plantio manual de mudas de árvores no Canadá, Stjernberg (1988a) observou que a percentagem de tempo gasto no plantio, em relação ao tempo total, foi igual a $66,0 \%$, variando entre 60,5 e 
$73,5 \%$. A velocidade média de plantio foi igual a $11,7 \mathrm{~s}$ por muda, variando entre 4,1 e 32,6 s por muda. $O$ autor concluiu que o tempo improdutivo pode ser minimizado e a velocidade de plantio incrementada, através das ações seguintes:

- Planejar o trabalho de preparo do solo visando as operações de plantio;

- Assegurar que a qualidade do preparo do solo seja aceitável, visando diminuir a necessidade de preparo manual;

- Selecionar ferramentas de plantio ergonomicamente bem projetadas;

- Selecionar os supervisores de campo com grande cuidado, pois eles necessitam possuir habilidade para trabalhar com pessoas, planejar e cumprir o trabalho, bem como tomar decisões;

- Treinar e motivar os trabalhadores rurais e supervisores para o plantio.

Em um trabalho realizado na Finlândia sobre o esforço do trabalho feito com a transplantadora de acionamento manual, Appelroth (1971) observou que os trabalhadores rurais apresentaram entre 98 batimentos por minuto (em um terreno considerado fácil para a execução dos serviços) e 115 batimentos por minuto (em um terreno considerado difícil para a execução dos serviços). Dessa maneira, a operação de plantio manual com a transplantadora foi classificada como um trabalho leve a meio pesado. $O$ autor concluiu que a principal vantagem da transplantadora de acionamento manual em relação à outras ferramentas de plantio manual é que o trabalhador rural não necessita se ajoelhar ou dobrar seus joelhos para realizar o plantio. A operação de plantio manual é desgastante para o trabalhador rural e deveria ser reconhecida como um trabalho muito exigente, tanto fisicamente quanto mentalmente (Balensiefer, 1978; Stjernberg, 1988a).

Examinando uma planilha de custos desenvolvida por Gonçalves et al. (2000) para povoamentos de eucaliptos em condições de cultivo mínimo 
do solo, observa-se que as operações manuais de plantio e replantio representam, respectivamente, $8,0 \%$ e $2,0 \%$ do valor total da reforma, estimado em US\$ 741 por hectare.

O plantio mecanizado é feito com as semeadoras, as plantadoras ou as transplantadoras. As semeadoras são máquinas destinadas ao plantio de espécies vegetais que se reproduzem por sementes. As plantadoras são máquinas empregadas no plantio de culturas que se reproduzem por órgãos vegetativos como raízes, colmos, tubérculos. As transplantadoras (Figura 2) são máquinas destinadas para plantar mudas produzidas em viveiros, como as essências florestais. As transplantadoras de acionamento mecânico são acopladas ao trator e operadas por um trabalhador rural que abastece 0 mecanismo com as mudas (Silveira, 1989).

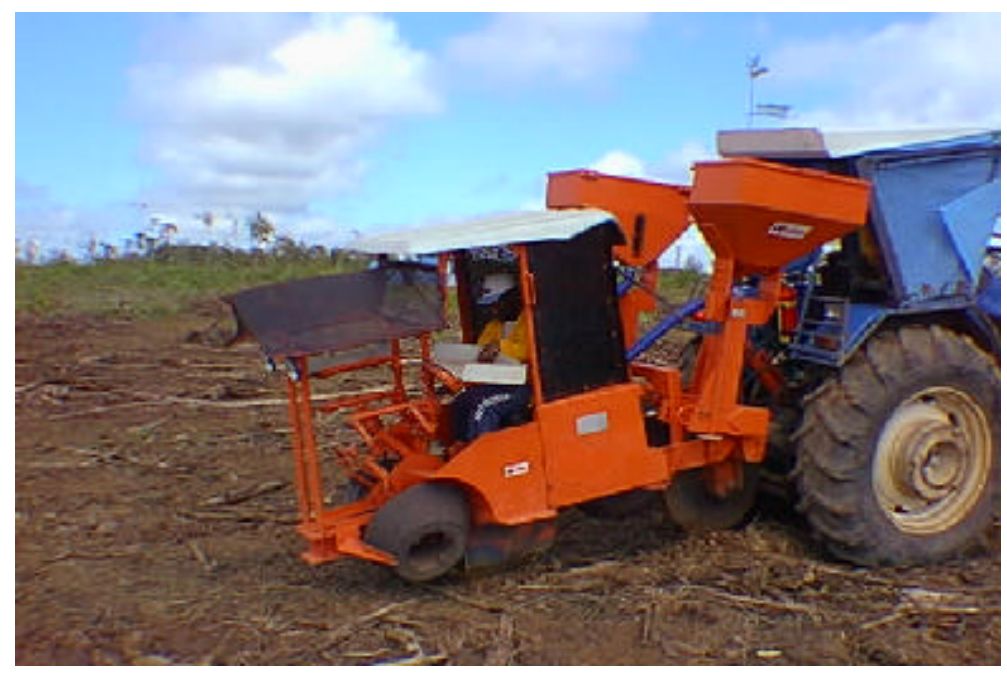

Figura 2 - Transplantadora de acionamento mecânico da marca Arador.

As transplantadoras de acionamento mecânico surgiram nos Estados Unidos em 1880, mas foi durante o período da Segunda Guerra Mundial que o seu desenvolvimento foi mais acentuado devido, principalmente, 
a limitada disponibilidade de mão-de-obra para executar o plantio manual (Trenk, 1963). A partir do sucesso inicial dos testes americanos feitos em Universidades, entre 1943 e 1945, as indústrias de máquinas agrícolas dos Estados Unidos e de outros países desenvolveram e testaram, nas décadas seguintes, implementos baseados em novos projetos (Aranda, 1993; Cormier \& Ryans, 1992; Cram, 1983; Fagundes, 1965-1966; Huang, 1973; Instituto de Pesquisa e Estudos Florestais - IPEF, 2000; Stjernberg, 1985; Stjernberg, 1992). Em pesquisa da década de 1970 sobre o uso das máquinas de plantio em trinta e um países do hemisfério norte, Appelroth (1974) concluiu que nos Estados Unidos, metade da área total anual de plantio já era feita mecanicamente naquela década.

O mecanismo transplantador das máquinas possui, geralmente, um disco vertical no qual as mudas são presas, sendo projetado para não danificar as mudas e evitar acidentes com o operador. As mudas são colocadas na parte superior do disco e com o deslocamento da máquina, o disco gira e a muda chega ao sulco, sendo liberada. Ao mesmo tempo, rodas situadas nos dois lados do sulco fazem a cobertura e a compactação do solo junto àmuda. Algumas máquinas possuem um sistema de irrigação no momento do plantio, sendo equipadas com tanques, tubulações, registros (Silveira, 1989).

Avaliando o plantio mecanizado de E. globulus no Chile, Aranda (1993) observou que a capacidade de campo efetiva média da máquina de transplantio foi de $0,99 \mathrm{ha} \mathrm{h}^{-1}$, variando entre 1,15 e 0,78 ha h $\mathrm{h}^{-1}$, em dez dias de trabalho. A máquina apresentou um tempo produtivo de $65,0 \%$ do tempo total e uma velocidade média estimada em 2,53 $\mathrm{km} \mathrm{h}^{-1}$, variando entre 1,49 e 3,02 km $h^{-1}$. 
Trabalhando no Canadá, com uma máquina de transplantio de mudas de árvores montada em um "forwarder", Cormier \& Ryans (1992) concluíram que, em boas condições do terreno, pode-se manter uma percentagem de tempo produtivo de $75,0 \%$ do tempo total e uma produtividade média de 1.500 mudas plantadas por hora. Os autores observaram também que, para atingir essa produtividade com operadores inexperientes, são necessários trinta dias de trabalho. Entretanto, a qualidade da operação, classificada pela profundidade do plantio, foi considerada ideal somente em $48,0 \%$ das mudas plantadas.

Em pesquisas periódicas do custo do plantio manual e do mecanizado nos Estados Unidos, entre 1952 e 1990, Straka et al. (1992) mostraram que o plantio manual foi, geralmente, 20,0 a 50,0\% mais caro que o mecanizado. Entretanto, Guildin (1982), avaliando o custo do plantio manual e do mecanizado nos Estados Unidos e em diversos tamanhos de parcelas quadradas, observou que para áreas menores que 40 ha o custo do plantio mecanizado sempre apresentou valores mais elevados que 0 feito manualmente.

No Brasil, a primeira transplantadora mecânica de mudas de árvores, desenvolvida em 1958, trabalhava em condições de cultivo intensivo do solo, preparado com arados e grades (Fagundes, 1965-1966). Seu uso nas décadas seguintes, porém, ficou restrito a plantios de mudas de Pinus de raiz nua na região Sul (Seixas, 1988b).

Estudando três métodos manuais e um mecanizado de plantio com P. taeda, Balensiefer (1978) observou que a percentagem de sobrevivência foi semelhante no sistema manual e no mecanizado. Nesse mesmo estudo foi concluído que a percentagem de tempo gasto no plantio, em relação ao tempo 
total, foi igual a $70,0 \%$ no sistema mecanizado, enquanto que no sistema manual foi igual a $81,0 \%$. O autor concluiu também que o número de mudas plantadas por pessoa, em um mesmo período de tempo, foi quatro vezes superior no sistema mecanizado em relação ao sistema manual. Entretanto, a estimativa de custo do plantio mecanizado foi $61,4 \%$ maior do que no manual.

Em meados da década de 1990 algumas transplantadoras mecânicas foram desenvolvidas para o cultivo de fumo, tomates e hortaliças no Estado de Santa Catarina, sendo que um desses modelos agrícolas foi adaptado e demonstrado, em 1999, para plantios de eucaliptos em condições de cultivo mínimo do solo, em áreas de uma empresa florestal do Estado de São Paulo (Souza Cruz, 1999; IPEF, 2000). Nessa transplantadora mecânica, da marca Metasa e modelo MTM-1000, as mudas são colocadas por um operador em um rotor de seis células. Quando uma dessas células se abre, a muda é liberada em um condutor e plantada no sulco do solo. Logo após, duas rodas compactadoras fecham o sulco e firmam as plantas no terreno. $A$ máquina pode realizar fertilização e irrigação intermitente, sincronizadas com 0 plantio (Metasa, 2002).

No setor agrícola, Rocha et al. (1991) argumentam que a aprovação do plantio mecanizado não irá depender somente da capacidade operacional de trabalho e do custo do equipamento, mas, principalmente, da precisão do plantio que a máquina possa oferecer em relação àoperação manual. 


\subsection{Qualidade total}

\subsubsection{Conceitos básicos da qualidade total}

O conceito da qualidade total é composto por cinco dimensões, a qualidade intrínseca, o custo, a entrega, o moral e a segurança. A qualidade intrínseca é o conjunto das características específicas que tornam um produto adequado à necessidades dos clientes; o custo se refere ao custo operacional para produzir o produto; a entrega significa entregar aos clientes a quantidade certa, no local e na data certa; o moral é a base da qualidade total e está relacionado com a equipe e o ambiente de trabalho; e segurança dever ser abordada tanto pelo uso seguro do produto pelo cliente, quanto pelo processo produtivo, isto é, sem acidentes de trabalho (Campos, 1992). A Figura 3 mostra, esquematicamente, a interação das cinco dimensões da qualidade total.

Uma definição simples da qualidade total é a adequação ao uso, ou seja, quando o produto ou processo satisfaz os seus usuários (Juran, 1990).

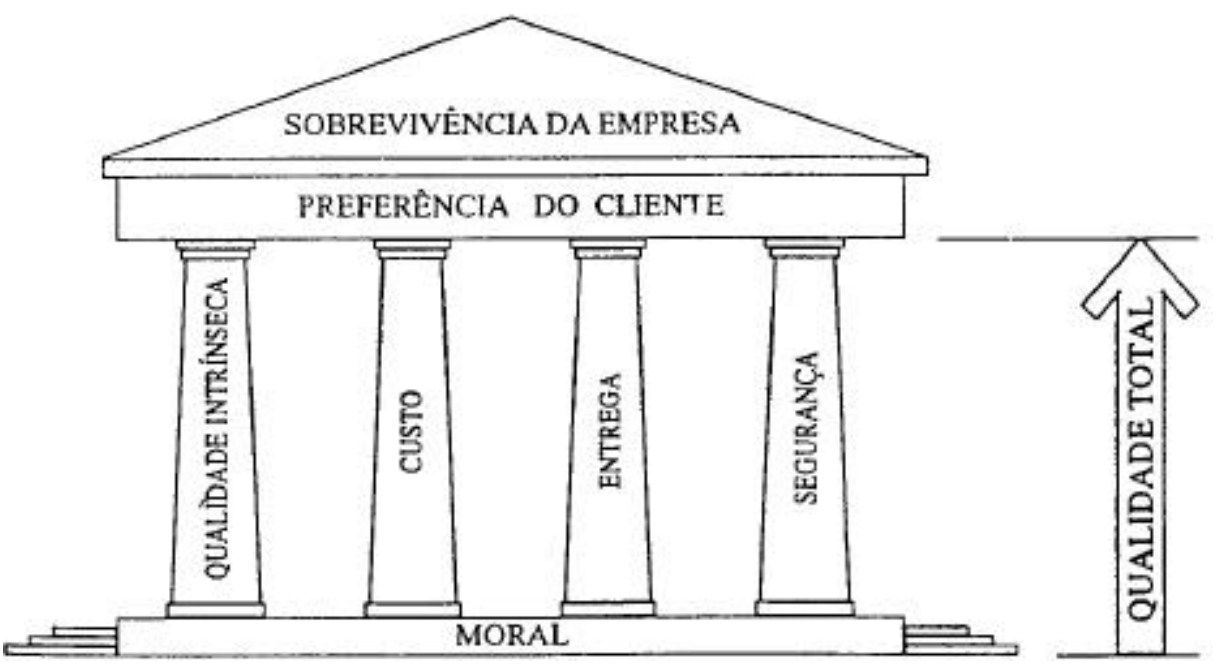

Figura 3 - Dimensões da qualidade total (Dellaretti Filho \& Drumond, 1994). 
O gerenciamento pela qualidade total implica em uma mudança de postura, e até mesmo de rompimento, dos gerentes e dos trabalhadores de uma empresa (Bonilla, 1994). O gerente deve ocupar-se com o desenvolvimento da tecnologia de trabalho dos empregados e estes, usar e manter essa tecnologia em um nível previsível. Dessa maneira, toda a hierarquia da empresa deve trabalhar para o empregado e este para o cliente (Dellaretti Filho \& Drumond, 1994).

A implantação do gerenciamento pela qualidade total deve iniciar-se com o controle da rotina diária do trabalho, através do ciclo PDCA (Bonilla, 1994; Dellaretti Filho \& Drumond, 1994). Cada letra do ciclo PDCA (Figura 4) está associada a uma fase do controle da rotina diária: P ("plan”) = planejar; D (“do”) = realizar; C (“check”) = verificar; e A (“action”) = corrigir (Trindade, 1993).

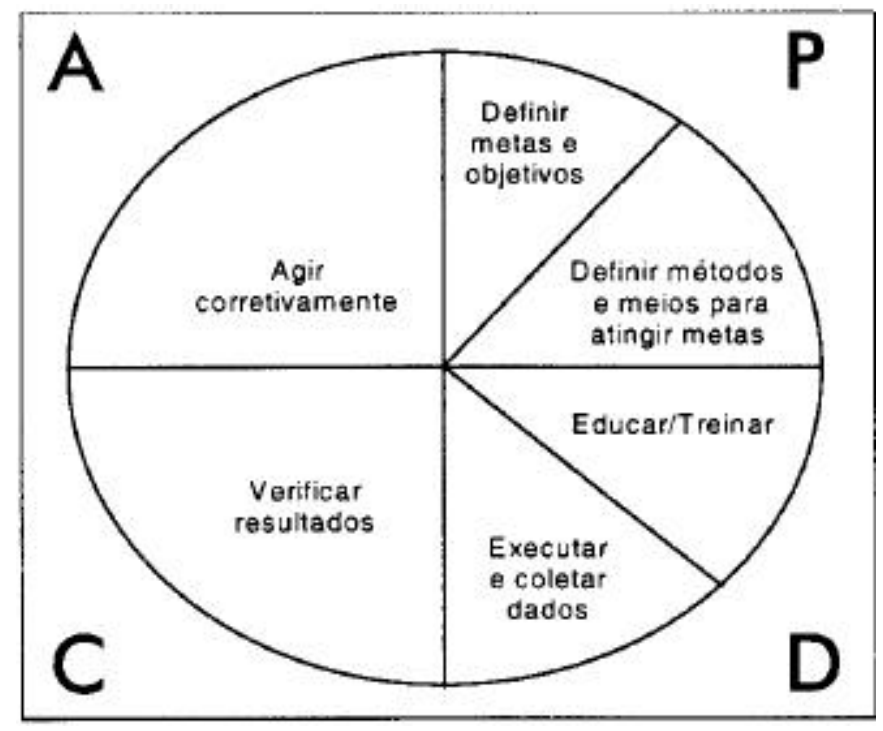

Figura 4 - Ciclo PDCA (Trindade et al., 2000).

A implementação do ciclo PDCA significa fazer regulagens preventivas nos processos produtivos, permitindo manter ou melhorar o nível de 
qualidade (Bonilla, 1994). O ciclo PDCA tem como base a teoria da melhoria contínua onde "hoje é melhor do que ontem e pior do que amanhã" (Milan, 1998, p.114).

\subsubsection{Avaliação de processos e produtos pela qualidade total}

Processo é a unidade fundamental do gerenciamento pela qualidade total, sendo definido como um conjunto de causas com o objetivo de produzir um efeito específico: o produto do processo (Dellaretti Filho \& Drumond, 1994).

Em um processo existem dois tipos de variação: comuns ou aleatórias; e causais ou não-aleatórias. As variações comuns são aquelas que ocorrem ao acaso e, individualmente, têm pequena influência no processo. As variações comuns são descritas pela distribuição normal (Figura 5). As variações causais são aquelas que podem alterar a normalidade do processo. Neste caso, os fatores da variação não podem ser explicados pela distribuição normal (Trindade et al., 2000).

A capacidade de um processo significa aquilo que ele é capaz de produzir se não existirem problemas comuns, sendo geralmente representada pelo intervalo entre $a \mu+3 \sigma$ e a $\mu-3 \sigma$ (Bonilla, 1994). 


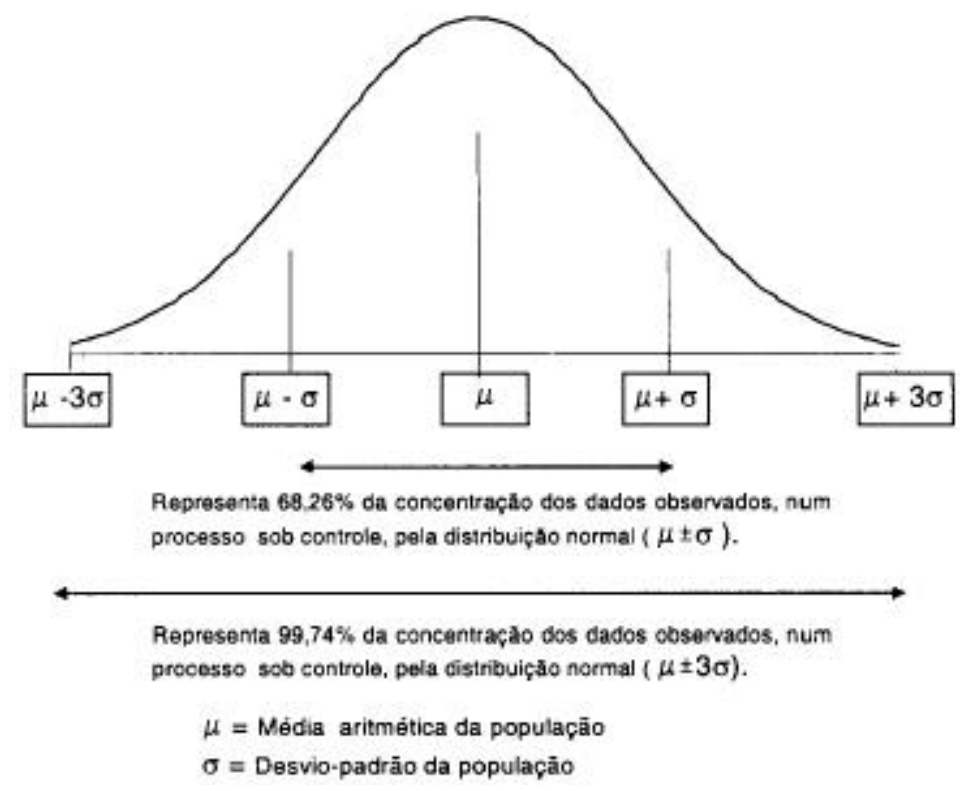

Figura 5 - Distribuição dos valores em um processo sob controle (Trindade et al., 2000).

Para determinar se um processo ou um produto está sob controle ou não, utilizam-se os itens de verificação, no processo, e os itens de controle, no produto (Dellaretti Filho \& Drumond, 1994). Os itens de verificação são indicadores que estão associados à causas que operam durante o processo, isto é, são as características medidas nas causas que influenciam o processo. Os itens de controle são indicadores que estão associados aos efeitos do processo, isto é, são as características medidas no produto acabado (Bonilla, 1994).

A avaliação de processos e produtos pela qualidade total é feita por variáveis e por atributos. A avaliação por variáveis consiste em se medir a variação obtida de modo quantitativo e, por isso, com mais objetividade $\mathrm{e}$ credibilidade. A avaliação por atributos refere-se a mensuração indireta, observando-se a variação obtida de modo qualitativo, sendo mais simplificada e 
rápida de ser feita. Pelas características das operações florestais, condicionadas aos prazos operacionais e æ̀ interações com o ambiente, a avaliação por atributos é preferida em relação à avaliação por variáveis (Almeida, 2000).

A avaliação por atributos deve ser priorizada quando existir (Paladini, 1990):

- Elevado número de itens a serem avaliados;

- Dificuldade de mensuração das variáveis;

- Maior relação de custo e benefício;

- Compatibilidade da inspeção visual; e

- Elevado volume de produção.

Uma das ferramentas não-estatísticas principais da qualidade total é o diagrama de causa e efeito, do tipo 6M (Figura 6), onde são relacionadas as causas do processo com os efeitos no produto. É utilizado quando se necessita identificar, explorar e ressaltar todas as causas possíveis de um problema. $O$ diagrama $6 \mathrm{M}$ enfoca as causas primárias do processo como 0 uso de máquinas, mão-de-obra, matéria-prima, método de trabalho, medição da atividade e sua relação com o meio ambiente (Trindade et al., 2000). 


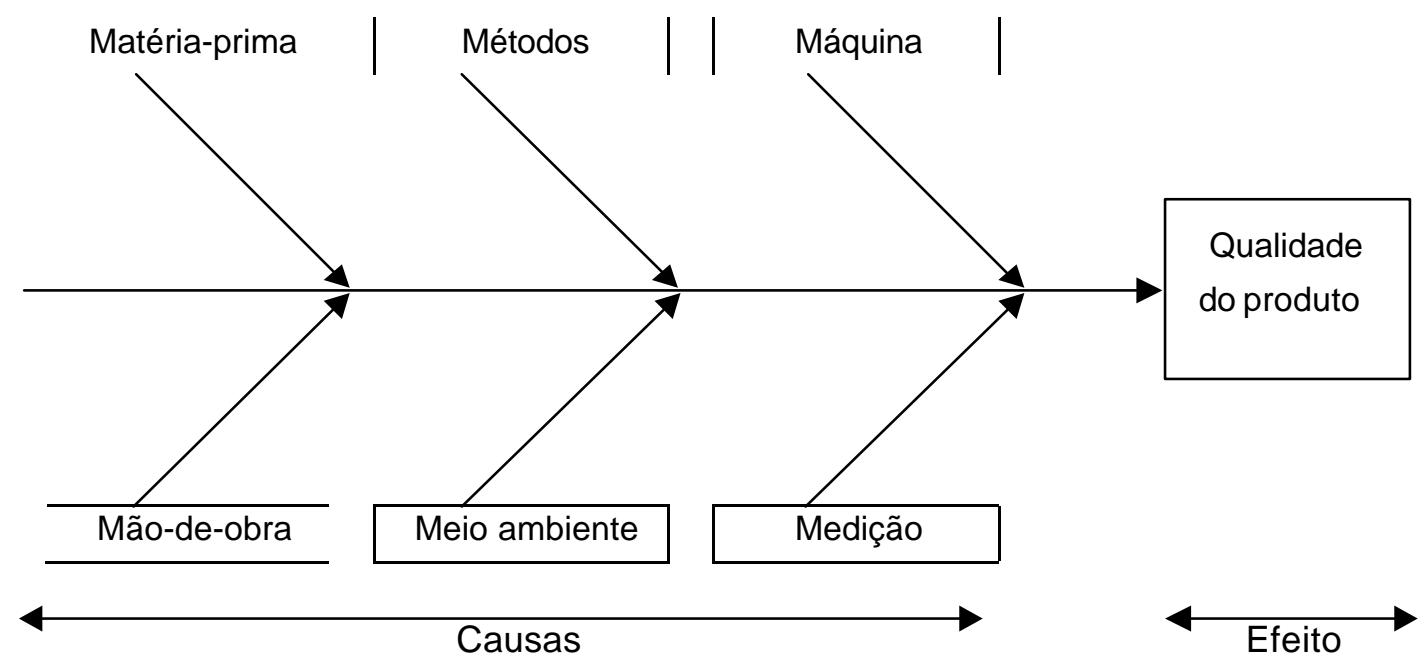

Figura 6 - Diagrama 6M (adaptado de Trindade et al., 2000).

As ferramentas estatísticas básicas da qualidade total são o histograma e os gráficos de Pareto, de dispersão e de controle. O histograma é um gráfico de barras para se visualizar uma determinada distribuição de dados por categoria, facilitando a análise de variabilidade em relação aos requisitos especificados. O gráfico de Pareto é composto por barras verticais, o que favorece a visualização quantitativa das causas de um problema e quais delas são mais representativas para uma determinada fonte de dados. A formatação do gráfico exibe a contribuição relativa das causas em relação ao efeito global. As principais causas correspondem a $80,0 \%$ do total. O gráfico de dispersão procura demonstrar a relação entre duas variáveis associadas. $O$ resultado da análise do gráfico de dispersão possibilita constatar se há uma possível relação de causa e efeito e sua intensidade. Normalmente se dispõe a causa no eixo da abscissa e o efeito no eixo da ordenada (Almeida, 2000).

O gráfico de controle (Figura 7) é composto por uma linha média, duas linhas (uma superior e outra inferior) que representam os limites de 
controle e os valores característicos do processo. Os limites de controle são estimados pelo valor médio, somado ou subtraído a três vezes o desvio padrão. Quando todos os pontos do gráfico localizam-se entre os limites de controle, considera-se que o processo está sob controle. Quando, no mínimo, um ponto localiza-se fora desses limites, considera-se que o processo está fora de controle (Bonilla, 1995).

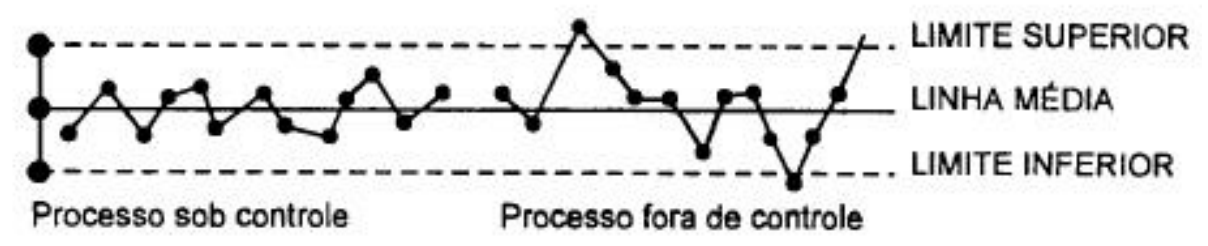

Figura 7 - Gráfico de controle: os pontos do gráfico representam a variação da qualidade em amostras seqüenciais (Bonilla, 1995).

A variação analisada pelo gráfico também pode estar fora de controle quando (Kume, 1993):

- Pelo menos 10 de 11 pontos consecutivos incidem num mesmo lado da linha central;

- Pelo menos 12 de 14 pontos consecutivos incidem num mesmo lado da linha central;

- Pelo menos 16 de 20 pontos consecutivos incidem num mesmo lado da linha central;

- Os pontos formam uma linha contínua ascendente ou descendente, apresentando uma tendência;

- Pelo menos 2 em 3 pontos consecutivos incidem próximos aos limites de controle; e

- A seqüência dos pontos mostra repetidamente uma tendência para cima e para baixo em intervalos quase sempre iguais. 
Os gráficos de controle básicos podem ser por variáveis ou por atributos. Os gráficos de controle por variáveis são usados quando a variação é obtida de modo quantitativo, podendo ser subdivididos em: gráficos da média pela amplitude e pelo desvio-padrão; e gráficos de dispersão do desvio-padrão e da amplitude. Os gráficos de controle por atributos são usados quando a variação é obtida de modo qualitativo, podendo ser subdivididos em gráfico da fração defeituosa e gráfico do número total de defeitos por unidade (Trindade et al., 2000).

\subsubsection{Qualidade total nas operações agrícolas e florestais}

Uma operação agrícola deve ser realizada com o objetivo de atender æ̀̀ exigências do próximo serviço a ser executado. Os defeitos de uma operação que prejudicam o próximo serviço são o foco da qualidade total e devem ser eliminados. Dessa maneira, a operação agrícola que prepara corretamente o terreno para a próxima, garante o seu sucesso (Lopes et al., 1995).

Em trabalho sobre o controle de qualidade em operações agrícolas mecanizadas, Pasqua (1999) avaliou a semeadura de milho, a adubação de cobertura e a aplicação de inseticida, concluindo que o uso dos métodos estatísticos do controle da qualidade mostrou-se uma ferramenta eficiente para a detecção de problemas no decorrer das operações.

Aplicando conceitos da qualidade em operações mecanizadas na produção de milho para silagem, Fernandes (2000) concluiu que a implantação do controle estatístico de processos, na operação de gradagem, reduziu o diâmetro dos torrões, provando ser útil para melhorar a qualidade da atividade. 
O primeiro trabalho sobre controle de qualidade no setor florestal brasileiro foi publicado em 1980, abrangendo as atividades de implantação, manutenção, exploração e de desbrota das florestas (Freitas et al., 1980). Em seguida, foram desenvolvidos os sistemas de vistorias ou auditorias de qualidade, logo difundidos para várias empresas do setor (Trindade et al., 2000). Porém, essas vistorias ou auditorias da qualidade apresentavam uma abordagem corretiva, ultrapassada no setor industrial, gerando problemas em várias empresas, tais como (Trindade, 1993):

- As operações eram avaliadas somente na vistoria, quando muitas delas não poderiam ser mais corrigidas;

- Os problemas que eram observados na vistoria nem sempre eram solucionados, devido a burocracia que dificultava a tomada de decisão;

- Os auditores da qualidade, quando erravam, eram criticados pelas equipes operacionais; e assim

- As vistorias eram consideradas como policiamento e geravam muitos atritos entre as equipes das empresas.

Analisando o desenvolvimento do uso do controle de qualidade em uma empresa florestal para a produção de carvão vegetal, Almeida (2000) observou que o caráter inspecionador do trabalho de rotina executado no campo, em meados da década de 1980, evoluiu para o controle de qualidade total, no início da década de 1990. A partir de então, segundo o autor, a empresa apresentou avanços na melhoria das condições de trabalho, treinamento e otimização de tarefas conforme os procedimentos operacionais, bem como o comportamento dos empregados em relação à solução dos problemas.

Desenvolvendo um sistema de controle de qualidade em uma empresa florestal, abrangendo desde a produção de mudas no viveiro até as 
operações de silvicultura no campo, Trindade (1993) concluiu que as técnicas de qualidade utilizadas no setor industrial podem ser aplicadas no setor florestal, desde que devidamente adequadas à situações existentes. $O$ autor concluiu também que, para garantir o correto funcionamento do sistema, o processo deve ser participativo, o que elimina atritos entre os empregados e equipes. Por fim, o sistema propiciou melhorias de qualidade em todo 0 processo produtivo.

Jacovine (2000), em um trabalho sobre gestão da qualidade na colheita de madeira, ressaltou que, na literatura, vários estudos sobre o controle da qualidade estão disponíveis, mas estes trabalhos são voltados para a área industrial. $\mathrm{Na}$ área florestal como um todo poucos estudos mostram a aplicação dos conceitos da qualidade total. As principais conclusões do trabalho foram:

- A qualidade operacional nos cinco sistemas de colheita de madeira avaliados é baixa;

- As especificações estabelecidas não são atendidas e o processo de colheita está fora de controle ou com tendência a sair de controle;

- O uso do controle estatístico de processo poderá contribuir na identificação dos pontos cruciais para a melhoria da qualidade operacional da colheita de madeira.

\subsection{Desempenho operacional e custo das máquinas agrícolas}

Define-se desempenho operacional das máquinas agrícolas como um complexo conjunto de informações que determinam seus atributos ao executarem operações sob determinadas condições de trabalho. Essas informações podem ter características: operacionais, relativas àq ualidade e à quantidade de trabalho; dinâmicas, relativas à potência requerida e à velocidade de trabalho; e de manejo, relativas às regulagens, aos reparos, à 
manutenções das máquinas. A avaliação das características operacionais, no caso dos tratores e implementos agrícolas, é feita pela capacidade de campo, a qual é estimada pela área trabalhada em uma unidade de tempo. A capacidade de campo pode ser teórica, efetiva ou operacional (Mialhe, 1974).

As capacidades de campo podem ser obtidas também pela largura de trabalho do implemento, multiplicada pela velocidade, sendo normalmente expressas em hectares por hora (Burla, 2001). A capacidade de campo teórica só é atingida se a máquina trabalhar $100,0 \%$ do tempo a velocidade nominal, utilizando $100,0 \%$ de sua largura de trabalho nominal. A capacidade de campo efetiva considera a largura e a velocidade efetiva de trabalho, valores obtidos somente durante a execução da operação para a qual a máquina foi projetada. A capacidade de campo operacional considera os tempos gastos com as manobras e as atividades auxiliares àoperação (ASAE, 2001b).

A capacidade de campo operacional tem sido conhecida como "rendimento operacional", terminologia que deve ser evitada, pois em mecanização agrícola rendimento é definido como uma relação entre capacidades de campo. O rendimento de campo é sinônimo de eficiência de campo (Mialhe, 1974).

O desempenho econômico das máquinas agrícolas é estimado pelos custos operacionais, os quais são divididos em custos fixos e variáveis (ou de uso). Os custos fixos são dependentes do tempo de propriedade da máquina, incluindo a depreciação, os juros, as taxas, os impostos, o seguro e o alojamento. Os custos de uso variam proporcionalmente com a utilização das máquinas, incluindo os gastos com o combustível, o lubrificante, os reparos, a manutenção e a mão-de-obra (Witney, 1988). 
Existem vários métodos propostos para se estimar os custos fixos e variáveis das máquinas agrícolas e florestais como nos trabalhos de Bortolai (1975), Hosokawa (1977a), Hosokawa (1977b), Oliveira (2000), Stohr (1977a) e Stohr (1977b). Entretanto, os especialistas da área de mecanização agrícola têm se orientado pelos métodos da ASAE, que nada mais fez do que juntar vários trabalhos executados em diferentes situações e com máquinas ou implementos semelhantes, sistematizando essas informações em várias equações (Molin \& Milan, 2000). 


\section{MATERIAL E MÉTODOS}

O trabalho foi conduzido em área de plantio de eucaliptos pertencente, com coordenadas geográficas $21^{\circ} 50^{\prime} 00^{\prime \prime} \mathrm{S}, 48^{\circ} 01^{\prime} 00^{\prime \prime}$ W e altitude de $685,0 \mathrm{~m}$. O clima da região experimental, segundo a classificação de Köeppen, é do tipo Cwa, ou seja, mesotérmico de inverno seco em que a temperatura média do mês mais frio (julho) tem sido inferior a $18,0^{\circ} \mathrm{C}$ e a do mês mais quente (janeiro) ultrapassa $22,0^{\circ} \mathrm{C}$. $\mathrm{O}$ total de chuvas no mês mais seco não tem ultrapassado $30,0 \mathrm{~mm}$. A precipitação média anual varia entre $1.100,0$ e $1.700,0 \mathrm{~mm}$. O talhão experimental possui 31,6 ha, sendo o relevo suave ondulado. O solo foi classificado como Neossolo Quartzarênico (RQ), segundo a Empresa Brasileira de Pesquisa Agropecuária - Embrapa (1999), sendo que as características físicas e químicas são apresentadas no Anexo A.

A área do ensaio vem sendo utilizada para o cultivo de povoamentos de Eucalyptus grandis e estava em primeira rotação, sendo que a colheita da madeira do povoamento foi feita por motosserras e o baldeio por "forwarders". A reforma seguiu o sistema de cultivo mínimo do solo, com plantio nas entre linhas do povoamento anterior e no espaçamento de 3,0 m entre linhas por 2,0 m entre plantas. As mudas de E. grandis utilizadas foram propagadas por sementes. Para a instalação do ensaio, o talhão foi dividido ao meio e em cada metade foi locada uma parcela amostral com tamanho de $2.250,0 \mathrm{~m}^{2}(30,0 \mathrm{~m} \times 75,0 \mathrm{~m})$. A coleta dos dados foi realizada no meses de julho e agosto de 2001. 


\subsection{Descrição das atividades de preparo do solo e de plantio}

Foram avaliadas as atividades de plantio manual e mecanizado de eucaliptos, através de itens de controle. As demais práticas silviculturais como o preparo do solo, o combate àformiga, a capina, a aplicação de fertilizante e a irrigação após o plantio, foram adotadas aquelas de uso corrente na empresa e semelhantes em toda a área do trabalho. Entre essas práticas silviculturais somente o preparo mecanizado do solo foi avaliado, através de itens de verificação.

\subsubsection{Preparo mecanizado do solo}

A operação de preparo do solo da empresa florestal foi realizada em conjunto com a fertilização de base. Utilizourse um subsolador de arrasto e adubadora da marca DMB, modelo SF-800A, com haste e aleta reguladas para atingir $0,40 \mathrm{~m}$ de profundidade no ponto central do sulco (especificação da empresa). O implemento foi tracionado por um trator $4 \times 2$ TDA da marca Valtra, modelo 1280R, com 92,7 kW de potência líquida do motor. Para executar a operação foi necessário um operador para o trator.

\subsubsection{Seleção das mudas para o plantio}

As mudas, ao chegarem no campo, foram selecionadas pela equipe de plantio da empresa florestal, descartando-se as plantas que não atendessem aos padrões da empresa: apresentar boa aparência, altura da parte aérea entre 0,250 m e 0,350 m, com presença de ponteiro não danificado, torrões firmes após o "desentubetamento" das mudas, raízes novas e não enoveladas 


\subsubsection{Sistemas de plantio}

Foram avaliados dois sistemas de plantio da empresa florestal: manual, feito por uma equipe experiente de trabalhadores rurais e com o uso da transplantadora de acionamento manual (Figura 8a) e mecanizado, realizado por uma máquina de transplantio de mudas da marca Metasa, modelo MTM1000 (Figura 8b), cujas características técnicas são apresentadas no Anexo B.

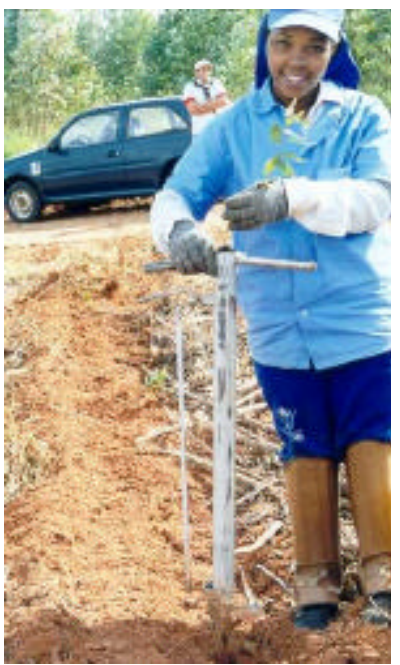

(a)

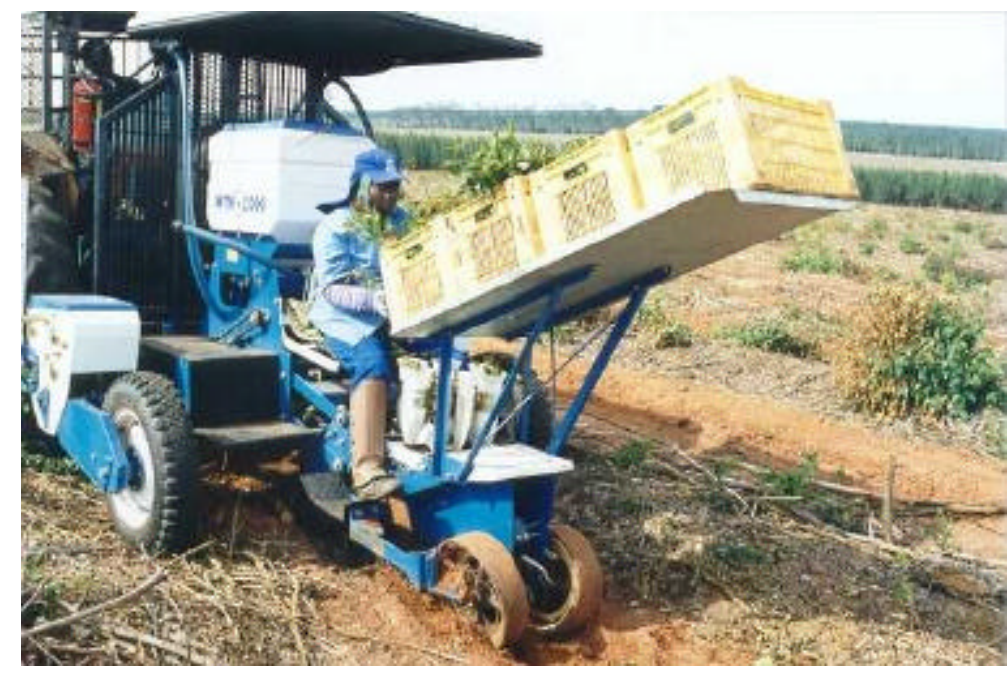

(b)

Figura 8 - Sistemas de plantio que foram estudados: a) manual; b) mecanizado.

O sistema de plantio feito com a transplantadora de acionamento manual seguiu a seguinte seqüência: marcação da distância entre plantas (2,0 m, especificação da empresa); plantio; e irrigação após o plantio. Foi utilizada uma carreta para a distribuição de mudas no talhão, da marca Fachini, acoplada a um trator $4 \times 2$ da marca Massey Ferguson, modelo MF265, com 47,8 kW de potência líquida do motor. Para executar a operação foram necessários onze 
trabalhadores rurais, um líder e um operador para o trator (equipe de plantio de tamanho padrão na empresa).

O sistema de plantio mecanizado dispensou a marcação manual de espaçamento, atividade feita pela máquina. A transplantadora foi regulada para trabalhar com 2,0 m de distância entre plantas, como no plantio manual. Ela realizou também uma irrigação intermitente sincronizada com o plantio, aplicando 1,0 L de água por planta, sob a superfície do solo, com o auxílio de dois reservatórios de 400,0 L montados àfrente e sobre o trator. A máquina foi acoplada ao engate de três pontos de um trator $4 \times 2$ da marca Massey Ferguson, modelo MF290, com 63,3 kW de potência líquida do motor. Para executar a operação mecanizada foi necessário um operador para o trator e um operador para a transplantadora.

\subsection{Amostragem e instalação das parcelas}

A metodologia de amostragem adotada no trabalho foi uma adaptação de Peche-Filho et al. (1994) e Fernandes (2000), que consideraram cada linha de preparo de solo e plantio como uma unidade amostral composta. Assim, foram amostradas vinte e cinco linhas de preparo do solo e plantio nos dois sistemas estudados, sistematicamente. Nessas linhas de preparo do solo e plantio foram levantados quinze pontos, formando uma malha de setenta e cinco pontos amostrais (Figura 9). A posição do ponto inicial da malha foi determinada pelo sorteio das distâncias aos carreadores. Somente as linhas de preparo e plantio com mais de $100,0 \mathrm{~m}$ de comprimento foram consideradas no sorteio. As parcelas foram instaladas a uma distância mínima de 15,0 m dos carreadores, reservando-se essa distância para a estabilização das atividades. 


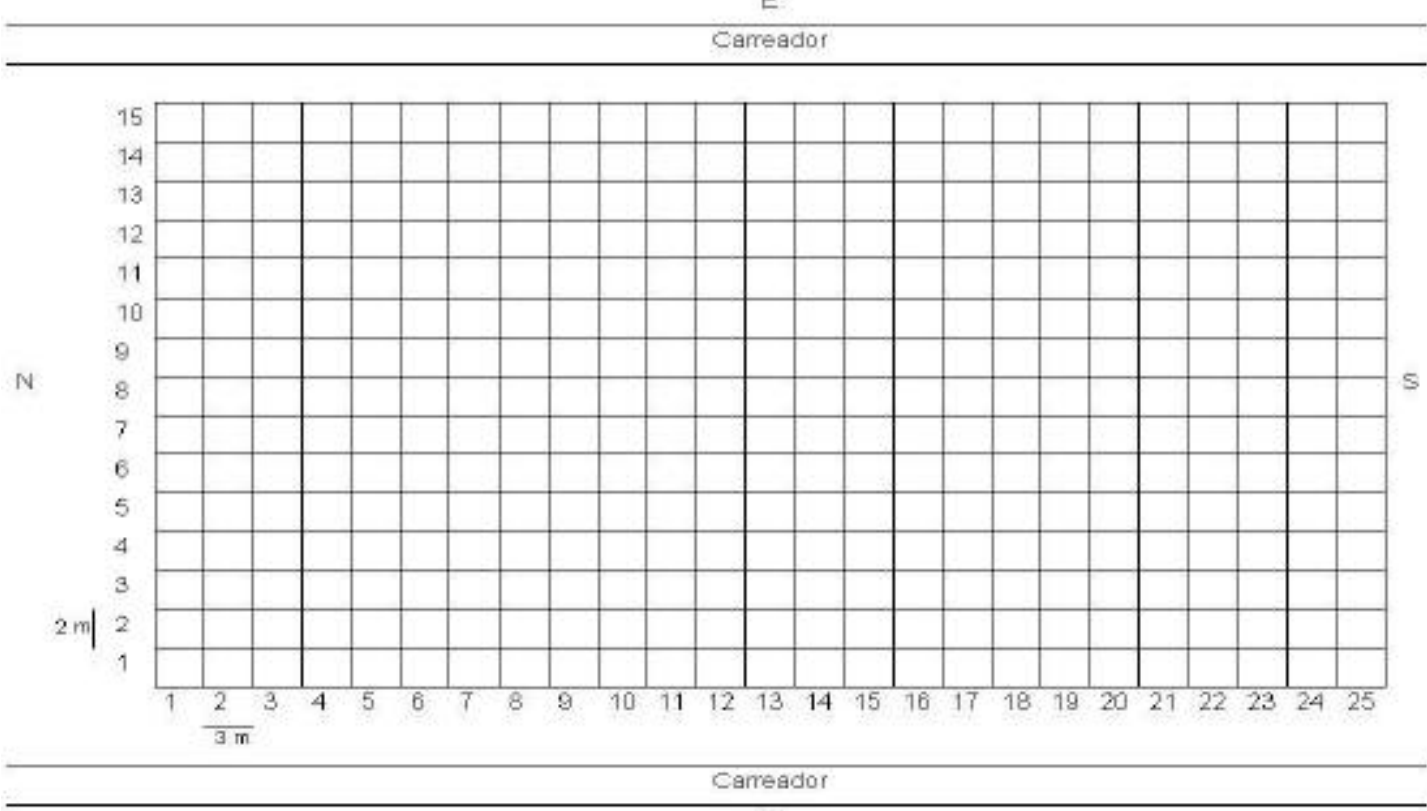

Figura 9 - Esquema de malha das parcelas mostrando as vinte e cinco linhas de preparo de solo e plantio (na horizontal) e os quinze pontos amostrais por linha (na vertical).

\subsection{Itens de verificação do preparo do solo que influenciam o plantio}

\subsubsection{Profundidade do sulco do preparo mecanizado do solo}

A amostragem da profundidade do sulco de preparo do solo foi feita em todos os quinze pontos amostrais de uma linha, mas somente em cinco linhas da malha. O levantamento foi sistemático, iniciado na primeira linha e a intervalos de cinco linhas de preparo do solo (Figura 10a). A profundidade do sulco até $0,60 \mathrm{~m}$ foi inferida através da estimativa da resistência do solo após o preparo. 
Para estimar a resistência do solo após o preparo, no sulco, utilizou-se o penetrômetro de impacto, modelo IAA/Planalsucar-Stolf, descrito por Stolf et al. (1983). Foram locados transectos, com o auxílio de uma trena, transversais ao sulco e composto de sete pontos de coleta. A amostragem foi iniciada no centro do sulco, caminhando-se tanto à esquerda quanto à direita até $0,3 \mathrm{~m}$ de distância e a intervalos regulares de 0,1 m (Figura 10b).

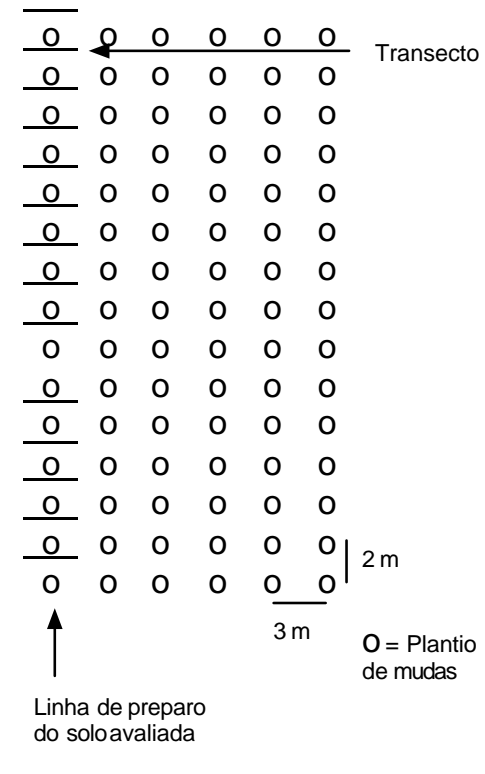

(a)

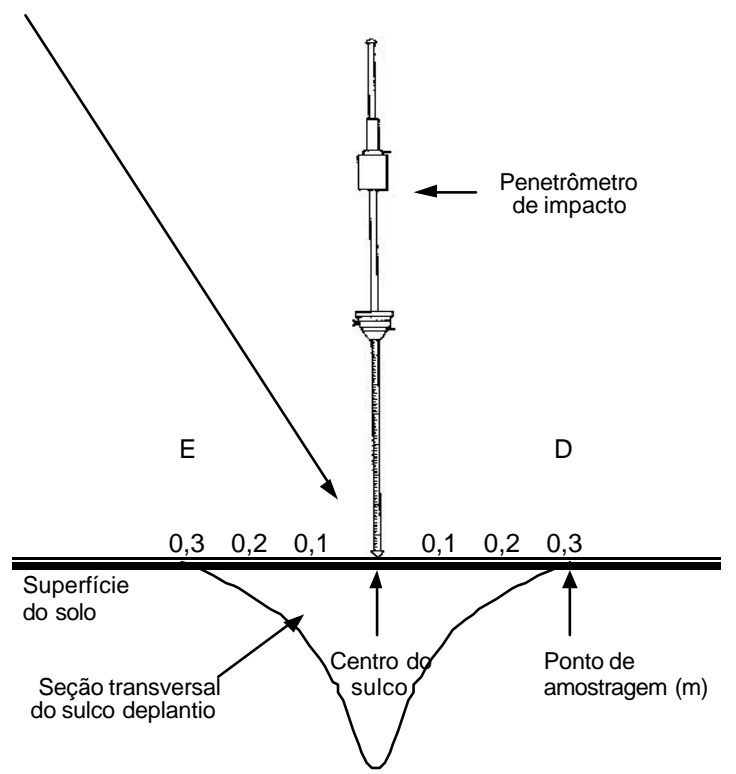

(b)

Figura 10 - Esquemas da amostragem da resistência do solo àpenetração, no sulco, após o preparo do solo: a) locações dos quinze transectos em uma linha de preparo do solo; e b) transecto mostrando o penetrômetro e os sete pontos amostrais $(E=$ a esquerda do centro do sulco; $\mathrm{D}$ = a direita do centro do sulco). 
Os dados coletados em impactos a cada $0,1 \mathrm{~m}$ de profundidade foram convertidos em força por unidade de área, segundo a fórmula proposta por Stolf (1991), para esse modelo de penetrômetro:

$$
R=5,58+(6,89 M)
$$

onde:

$\mathrm{R}$ é a resistência do solo àpenetração ou índice de cone $\left(\mathrm{kgf} \mathrm{cm}^{-2}\right)$;

$\mathrm{N}$ é o número de impactos a cada $0,1 \mathrm{~m}$ de profundidade no solo penetrado pela ponta do cone do aparelho.

O solo foi considerado mobilizado quando o número de impactos a cada $0,1 \mathrm{~m}$ de profundidade foi igual a zero, ou seja, o valor da resistência do solo à penetração foi inferior a $5,58 \mathrm{kgf} \mathrm{cm}^{-2}(0,55 \mathrm{MPa})$. O valor, segundo Stolf (1991), corresponde a relação entre o peso do penetrômetro (7,20 kgf) e a área do cone de penetração do aparelho $\left(1,29 \mathrm{~cm}^{2}\right)$. Representa, assim, a pressão exercida pelo penetrômetro quando em repouso vertical sobre o solo. A profundidade do sulco de plantio, então, foi inferida até esse limite. $O$ procedimento descrito é específico para o modelo de penetrômetro utilizado.

O teor de água do solo foi avaliado por coletas aleatórias de dez amostras de solo por parcela, nas camadas de 0,0 a 0,2 m e 0,2 a 0,4 m, durante as amostragens com o penetrômetro (Tabela 1). Utilizourse o método gravimétrico para a determinação da umidade do solo (Embrapa, 1997). 
Tabela 1. Teor de água dos solos após o preparo.

\begin{tabular}{lccc}
\hline Parcela & $0,0-0,2 \mathrm{~m}$ & $\begin{array}{r}\text { Teor de água } \\
0,2-0,4 \mathrm{~m}\end{array}$ & Média \\
\hline Manual & 5,0 & \% por massa & 3,9 \\
Mecanizada & 6,2 & 2,7 & 5,3 \\
\hline
\end{tabular}

\subsubsection{Diâmetro dos torrões sobre a linha central do sulco}

A amostragem do diâmetro dos torrões, após o preparo do solo, foi feita no sentido longitudinal ìs linhas de preparo, na projeção do ponto central do sulco. Foram realizadas quinze amostragens em cada um das vinte e cinco linhas de preparo do solo avaliadas (Figura 11). Utilizourse uma metodologia adaptada de Laflen et al. (1981), com o uso de uma haste linear de madeira de 1,50 $\mathrm{m}$ de comprimento e dividida em dez partes distanciadas de $0,15 \mathrm{~m}$ uma da outra. Somente os torrões que coincidiram, pelo menos em parte, com as marcas da haste, tiveram o diâmetro medido com uma fita métrica (Figura 12). 


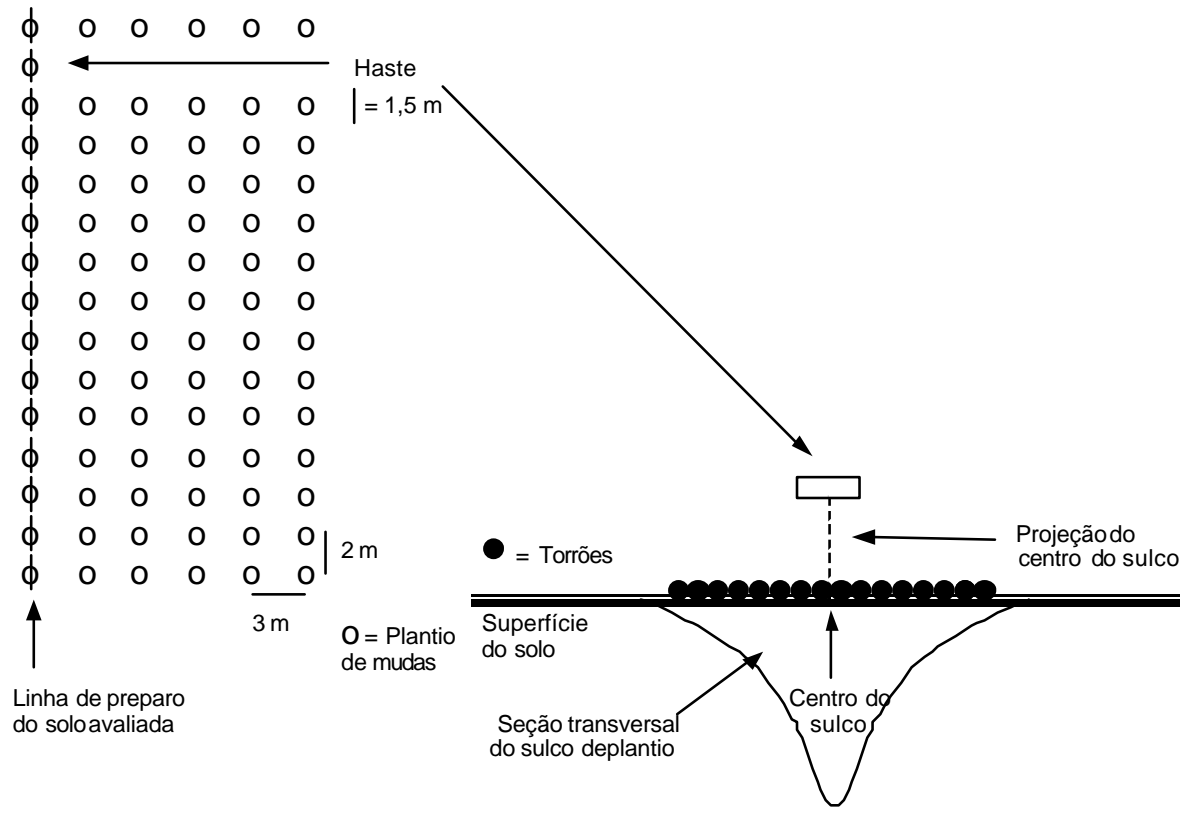

(a)

(b)

Figura 11 - Esquemas da amostragem do diâmetro dos torrões, na projeção do centro do sulco, após o preparo do solo: a) locações dos pontos de amostragem com a haste em uma linha de preparo do solo; e b) amostra mostrando a haste, os torrões e o sulco de preparo do solo. 
$1,50 \mathrm{~m}$

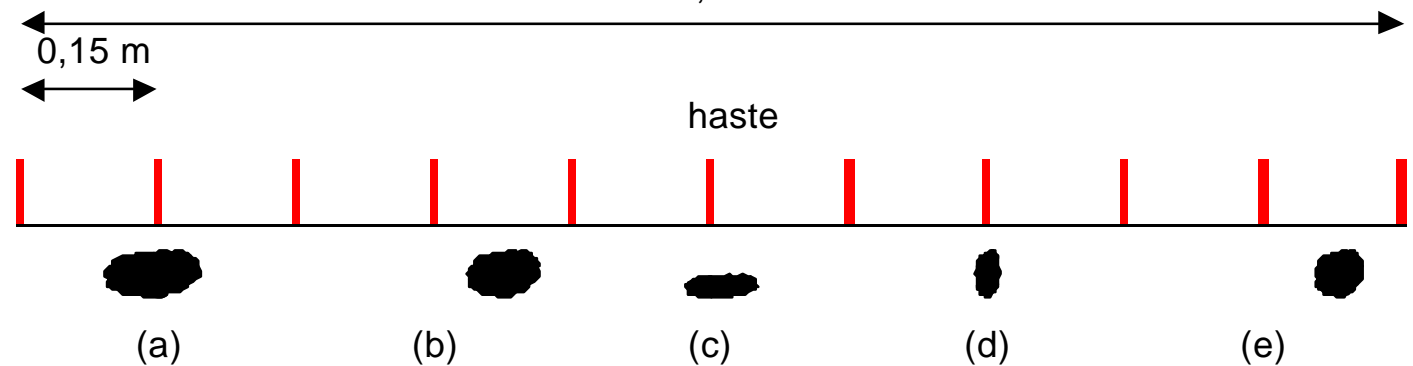

Figura 12 - Esquema mostrando a haste e os pontos de amostragem dos torrões (em vermelho). No exemplo, somente seriam medidos os torrões dos pontos a, c e d, pois foram os que coincidiram com as marcas vermelhas da haste.

\subsubsection{Volume cilíndrico dos galhos de madeira sobre a faixa de sulcamento}

Foram amostrados, após o preparo do solo, os galhos provenientes dos restos da colheita florestal localizados sobre a faixa de sulcamento $(0,6 \mathrm{~m} \times 45,0 \mathrm{~m})$. Foram locadas quinze amostras em cada uma das vinte e cinco linhas de preparo do solo avaliadas (Figura 13). A área de cada amostra foi igual a $1,0 \mathrm{~m}^{2}(0,6 \mathrm{~m} \times 1,7 \mathrm{~m})$. Somente os galhos com diâmetro superior a $0,01 \mathrm{~m}$, localizados nessa área, foram avaliados com uma fita métrica. As dimensões medidas foram o diâmetro e o comprimento, os quais permitiram estimar o volume cilíndrico de galhos por unidade de área. 


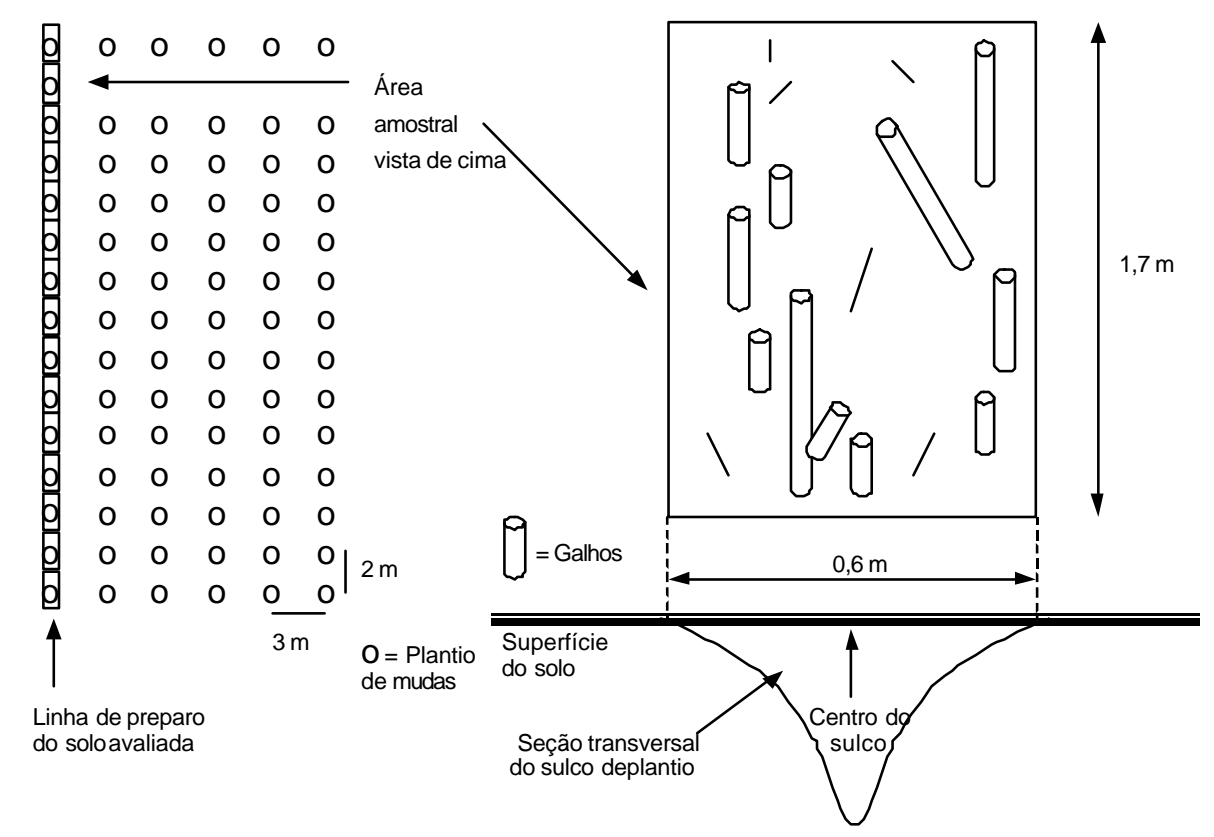

(a)

(b)

Figura 13 - Esquemas da amostragem dos galhos sobre a faixa de sulcamento, após o preparo do solo: a) locações das áreas amostrais em uma linha de preparo do solo; e b) área amostral mostrando os galhos e o sulco de preparo do solo.

\subsection{Itens de controle dos sistemas de plantio}

Todas as plantas das duas parcelas de estudo foram classificadas visualmente após o plantio segundo os atributos seguintes, selecionados em conjunto com a equipe técnica da empresa florestal:

- Muda plantada apresentando substrato exposto, acima da superfície do solo;

- Muda plantada com o colo encoberto pelo solo;

- Muda plantada inclinada;

- Muda plantada apresentando folhas danificadas ou ausentes;

- Muda plantada com ponteiro danificado ou ausente; 
- Muda plantada sem firmeza;

- Muda plantada fora do sulco de preparo do solo;

- Muda enterrada nas camadas subsuperficiais do solo;

- Muda jogada sobre a superfície do solo; e

- Muda não plantada.

Cada atributo foi considerado como um defeito do plantio. A distância entre plantas e a altura da parte aérea das mudas foram medidas, com uma fita métrica, logo após o plantio. No primeiro mês de idade foi medida a altura da parte aérea das plantas e avaliada a sobrevivência dos plantios.

\subsection{Ferramentas da qualidade total utilizadas}

A análise dos itens de verificação e de controle das operações foi realizada através dos histogramas, dos gráficos de Pareto, dos gráficos de controle e do diagrama de causa e efeito $6 \mathrm{M}$, de acordo com a metodologia proposta por Trindade et al. (2000) para o setor florestal. A elaboração dos histogramas e gráficos foi feita no programa Microsoft Excel ${ }^{1}$, seguindo as etapas propostas por Alves \& Pieske (1997). Os tipos de gráficos de controle utilizados foram: média; desvio padrão; amplitude; e número total de defeitos por unidade. Os fatores de ajuste àdistribuição normal $\left(c_{2}, c_{3}, c_{4}, d_{3}\right.$ e $\left.d_{4}\right)$ para a estimativa dos limites de controle foram reproduzidos de Paladini (1990) e encontram-se no Anexo C. Para estimar as linhas médias e os limites dos gráficos de controle foram usadas as equações seguintes (Trindade et al., 2000):

\footnotetext{
${ }^{1}$ Marca registrada da Microsoft Corporation.
} 


\subsubsection{Gráfico de controle da média}

$$
\begin{gathered}
L M=\bar{X} \\
L S C=\bar{X}+3 \frac{\bar{S}}{c_{2} \sqrt{n}} \\
L I C=\bar{X}-3 \frac{\bar{S}}{c_{2} \sqrt{n}}
\end{gathered}
$$

onde:

LM é a linha média;

$X$ é o valor médio;

LSC é o limite superior de controle;

$S$ é o desvio médio;

$\mathrm{C}_{2}$ é o fator de ajuste àdistribuição normal, tabelado em função de n;

$\mathrm{n}$ é o tamanho da amostra;

LIC é o limite inferior de controle.

\subsubsection{Gráfico de controle do desvio-padrão}

$$
\begin{gathered}
L M=\bar{S} \\
L S C=\bar{S} C_{4} \\
L I C=\bar{S} C_{3}
\end{gathered}
$$

onde:

LM é a linha média; 
S é o desvio médio;

LSC é o limite superior de controle;

$c_{3}$ e $c_{4}$ são fatores de ajuste àdistribuição normal, tabelados em função de $n$;

LIC é o limite inferior de controle.

\subsubsection{Gráfico de controle da amplitude}

$$
\begin{gathered}
L M=\bar{R} \\
L S C=\bar{R} d_{4} \\
L I C=\bar{R} d_{3}
\end{gathered}
$$

onde:

LM é a linha média;

$R$ é a amplitude média;

LSC é o limite superior de controle;

$\mathrm{d}_{3}$ e $\mathrm{d}_{4}$ são fatores de ajuste àdistribuição normal, tabelados em função de $\mathrm{n}$; LIC é o limite inferior de controle.

3.5.4 Gráfico de controle do número total de defeitos por unidade

$$
\begin{gathered}
L M=\bar{u} \\
L S C=\bar{u}+3 \sqrt{\bar{u}} \\
L I C=\bar{u}-3 \sqrt{\bar{u}}
\end{gathered}
$$


onde:

LM é a linha média;

u é a razão entre o número de defeitos em todas as amostras e o número de unidades em todas as amostras;

LSC é o limite superior de controle;

LIC é o limite inferior de controle.

\subsection{Análises estatísticas dos resultados}

A comparação das médias das variáveis, entre as parcelas, foi realizada pelo teste $t$ não-pareado. As comparações das percentagens de defeitos do plantio e da percentagem de sobrevivência, entre as parcelas, foram feitas pelo teste não-paramétrico de qui-quadrado. Utilizou-se o sistema SAS ${ }^{2}$ para realizar as análises estatísticas, ao nível de significância de 5,0\%.

\subsection{Estimativas operacionais dos sistemas de plantio}

\subsubsection{Desempenho operacional}

Cada sistema de plantio foi avaliado durante uma semana de trabalho (cinco dias com jornada de 8 horas). No sistema de plantio manual registrou-se somente o tempo total gasto com a operação. No sistema de plantio mecanizado registrou-se os tempos trabalhados, acessórios e auxiliares da operação. Os tempos gastos com manobras foram considerados acessórios e os tempos gastos com abastecimentos ou regulagens foram considerados auxiliares, seguindo a metodologia de Gonçalves et al. (1993). Para avaliar esses tempos utilizourse um relógio digital.

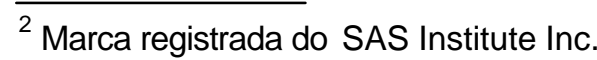


A estimativa da capacidade de campo seguiu a metodologia de Mialhe (1974). Para o sistema de plantio manual foi estimada somente a capacidade de campo operacional, ou seja, a razão entre a área trabalhada e o tempo total gasto com a operação. Para o sistema de plantio mecanizado foram estimadas a capacidade de campo efetiva, segundo a eq. (13), e a capacidade de campo operacional, segundo a eq. (14):

$$
C_{c} E=\frac{L_{e} V_{e}}{10}
$$

onde:

$\mathrm{C}_{\mathrm{c}} \mathrm{E}$ é a capacidade de campo efetiva $\left(\mathrm{ha}^{-1}\right)$;

$L_{e}$ é a largura efetiva de trabalho $(m)$;

$V_{e}$ é a velocidade efetiva de trabalho $\left(\mathrm{km} \mathrm{h}^{-1}\right)$;

$$
C_{c} O=\frac{C_{c} E}{T_{p r o}+T_{a c e}+T_{a u x}}
$$

onde:

$\mathrm{C}_{\mathrm{c}} \mathrm{O}$ é a capacidade de campo operacional $\left(\mathrm{ha}^{-1}\right)$;

$\mathrm{C}_{\mathrm{C}} \mathrm{E}$ é a capacidade de campo efetiva $\left(\right.$ ha $\left.\mathrm{h}^{-1}\right)$;

Tpro é o tempo produtivo (h);

Tace é o tempo acessório despendido com as manobras da máquina ( $h$ );

$T_{\text {aux }}$ é o tempo auxiliar despendido com o abastecimento dos tanques de água, carregamento das mudas, bem como com as regulagens da máquina ( $h$ ). 


\subsubsection{Custo operacional}

Os custos estimados no trabalho consideraram apenas a operação de plantio, não envolvendo os custos de transporte das mudas até o local do estudo e o replantio.

Os custos, nos dois sistemas de plantio, foram estimados pela soma dos custos fixos e custos variáveis, segundo metodologias adaptadas da ASAE (2001c; 2001d). Os fatores da ASAE para a estimativa do custo operacional das máquinas encontram-se no Anexo D. Os preços de compra das máquinas novas e as suas vidas úteis, encontram-se no Anexo E. Os salários dos operadores de tratores, líderes de equipe e trabalhadores rurais, encontram-se no Anexo F. Os preços das máquinas, óleo lubrificante, combustível e mão-de-obra foram coletados em junho de 2002.

\subsubsection{Custo fixo horário das máquinas}

Para estimar o custo fixo horário das máquinas com a depreciação, os juros, o alojamento, os seguros e os impostos, utilizou-se a eq. (15):

$$
C_{r}=\frac{V_{n}\left[\left(\frac{1-V_{r a}}{V_{u}}\right)+\left(\frac{1+V_{r a}}{2}\right) I+A S I\right]}{N_{n t a}}
$$

onde:

$\mathrm{C}_{\mathrm{f}}$ é o custo fixo horário $\left(\mathrm{R} \$ \mathrm{~h}^{-1}\right)$;

$\mathrm{V}_{\mathrm{n}}$ ó preço de compra da máquina nova, consultado junto ao fabricante $(\mathrm{R} \$)$; 
$V_{r d}$ é o valor de revenda da máquina, no último ano da sua vida útil (decimal);

$\mathrm{V}_{\mathrm{u}}$ é a vida útil da máquina, estimada junto ao fabricante (anos);

I é a taxa de juros anual, fixada em 8,8\% (decimal);

ASI é o valor do alojamento, dos seguros e dos impostos, padronizado em 2,0\% segundo ASAE (2001c) (decimal);

$\mathrm{N}_{\text {hta }}$ é o número de horas disponível para o trabalho no ano.

O valor de revenda em decimal $\left(V_{\text {rd }}\right)$ foi obtido pela razão entre o preço de revenda em real $\left(\mathrm{V}_{\mathrm{rr}}\right)$ e o preço de compra da máquina nova $\left(\mathrm{V}_{\mathrm{n}}\right)$. $\mathrm{O}$ preço de revenda em real foi estimado através do método de depreciação pelo saldo decrescente, segundo a eq. (16):

$$
V_{r r}=V_{r} F_{c p a}\left(F_{d a}\right)^{i m q}
$$

onde:

$V_{r r}$ é o preço de revenda da máquina, no último ano da sua vida útil $(R \$)$;

$V_{n}$ é o preço de compra da máquina nova, consultado junto ao fabricante $(R \$)$;

$F_{\mathrm{cpa}}$ é o fator de correção da depreciação para o primeiro ano, padronizado segundo ASAE (Witney, 1988);

$F_{d a}$ é o fator da depreciação anual, padronizado segundo ASAE (Witney, 1988);

imq é a idade da máquina, no último ano da sua vida útil (anos).

O número de horas disponível para o trabalho no ano foi estimado segundo a eq. (17), proposta por Mialhe (1974):

$$
N_{h t a}=\left[N-\left(n_{d f}+n_{d u u}\right)\right] H_{j t d}
$$

onde:

$N_{\text {hta }}$ é o número de horas disponível para o trabalho no ano; 
N é o número total de dias do período;

$\mathrm{n}_{\mathrm{df}}$ é o número de domingos e feriados no ano;

$\mathrm{n}_{\text {duu }}$ é o número de dias úteis úmidos no ano;

$H_{\text {jtd }}$ é número de horas da jornada diária de trabalho.

O número total de dias do período foi igual a 365 (um ano). 0 número de domingos e feriados foi igual a 66 no ano. O número de dias úteis úmidos foi estimado pelo número mínimo de dias agronomicamente secos no ano, para solo arenoso, e seguiu a tabela proposta por Mialhe (1974). Nessa tabela, a cidade de lbaté (local do ensaio), pertencente a região de Jaú, apresenta no mínimo 266 dias agronomicamente secos, para solo arenoso. Assim, para estimar o número de dias úteis úmidos utilizourse a eq. (18):

$$
n_{\text {duu }}=\left(1-\frac{n_{\text {das }}}{N}\right)\left(N-n_{d f}\right)
$$

onde:

$\mathrm{n}_{\text {duu }}$ é o número de dias úteis úmidos no ano;

$\mathrm{n}_{\text {das }}$ é o número de dias agronomicamente secos, tabelado segundo Mialhe (1974);

N é o número total de dias do período;

ndf é o número de domingos e feriados no ano.

O número de dias úteis úmidos foi igual, então, a 81 . A jornada diária de trabalho foi igual a 8 horas. 


\subsubsection{Custo variável horário das máquinas}

Para estimar o custo variável horário dos tratores, em reais por hora, somou-se o custo com os reparos e a manutenção, com o combustível (diesel) e com o óleo lubrificante (diesel). Para as outras máquinas, o custo variável horário foi igual ao custo com os reparos e a manutenção.

O custo horário com os reparos e a manutenção foi estimado segundo a eq. (19):

$$
C_{r m}=\frac{R F 1 V\left(\frac{h}{1000}\right)^{R F 2}}{h}
$$

onde:

$C_{r m}$ é o custo horário com os reparos e com a manutenção $\left(R \$ h^{-1}\right)$;

RF1 e RF2 são os fatores dos reparos e da manutenção, padronizados segundo ASAE (2001d);

$\mathrm{V}_{\mathrm{n}}$ é o preço de compra da máquina nova, consultado junto ao fabricante $(\mathrm{R} \$)$;

h são as horas de uso das máquinas até a depreciação, padronizados segundo ASAE (2001d).

O custo horário com o combustível e com o óleo lubrificante foi estimado segundo ASAE (2001d). O custo com o combustível foi estimado pela eq. (20):

$$
C_{c b}=P_{l m t} 0,163 P_{c b}
$$


onde:

$\mathrm{C}_{\mathrm{cb}}$ é o custo horário com o combustível $\left(\mathrm{R} \$ \mathrm{~h}^{-1}\right)$;

$\mathrm{P}_{\mathrm{Imt}}$ é a potência líquida do motor do trator $(\mathrm{kW})$;

$P_{c b}$ é o preço do litro do combustível, considerado a $R \$ 1,00 L^{-1}$.

O custo horário com o óleo lubrificante foi estimado pela eq. (21):

$$
C_{o l}=\left(0,00059 P_{I m t}+0,02169\right) P_{o l}
$$

onde:

$\mathrm{C}_{\text {ol }}$ é o custo horário com o óleo lubrificante $\left(R \$ \mathrm{~h}^{-1}\right)$;

$\mathrm{P}_{\mathrm{Imt}}$ é a potência líquida do motor do trator $(\mathrm{kW})$;

$\mathrm{P}_{\text {ol }}$ é o preço do litro do óleo lubrificante, considerado a $R \$ 3,50 \mathrm{~L}^{-1}$.

\subsubsection{Custo variável horário da mão-de-obra}

O custo horário com a mão-de-obra, além de ter incluído os salários diretos dos trabalhadores, considerou o custo indireto das obrigações sociais. Para realizar a estimativa utilizou-se a eq. (22):

$$
C_{h m o}=\frac{12 S_{m}(1+f)}{N_{h t a}}
$$

onde:

$\mathrm{C}_{\mathrm{hmo}}$ é o custo horário da mão-de-obra $\left(\mathrm{R} \$ \mathrm{~h}^{-1}\right)$;

$S_{m}$ é o salário mensal $(R \$)$;

f são os custos das obrigações sociais, considerado em 100,0\% (decimal);

$\mathrm{N}_{\text {hta }}$ é o número de horas disponível para o trabalho no ano. 


\subsubsection{Custo horário total dos sistemas de plantio}

A estimativa do custo horário total dos sistemas de plantio foi feita pela soma dos custos fixos e variáveis, incluindo a mão-de-obra.

\subsubsection{Custo operacional dos sistemas de plantio}

A estimativa do custo operacional foi obtida pela eq. (23):

$$
C_{o p}=\frac{C_{h r}}{C_{c} O}
$$

onde:

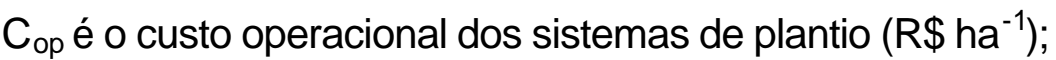

$\mathrm{C}_{\mathrm{hr}}$ é o custo horário dos sistemas de plantio $\left(\mathrm{R} \$ \mathrm{~h}^{-1}\right)$;

$\mathrm{C}_{\mathrm{c}} \mathrm{O}$ é a capacidade de campo operacional dos sistemas de plantio ( $\mathrm{ha} \mathrm{h}^{-1}$ ). 


\section{RESULTADOS E DISCUSSÃO}

\subsection{Itens de verificação do preparo do solo que influenciaram o plantio}

\subsubsection{Profundidade do sulco do preparo mecanizado do solo}

$\mathrm{Na}$ Figura 14 são apresentados os resultados médios referentes à profundidade do sulco de preparo do solo. No talhão do estudo, a profundidade média encontrada foi de 0,32 $\mathrm{m}$, variando entre $0,18 \mathrm{~m}$ e 0,46 $\mathrm{m}$. Somente $16,0 \%$ dos 75 pontos amostrais apresentaram profundidade igual ou superior, no centro do sulco, a $0,40 \mathrm{~m}$ (especificação da empresa) (Figura 14). O valor mais freqüente da profundidade foi de $0,33 \mathrm{~m}$, ocorrendo em $9,3 \%$ dos 75 pontos amostrais.

Analisando-se os gráficos de controle da profundidade de preparo do solo, observou-se a presença de vários pontos fora dos limites em todas as cinco linhas de trabalho e na maioria $(92,0 \%)$ dos setenta e cinco transectos amostrados, o que caracterizou a falta de controle para a variável analisada (Figura 15). Isso significou que causas não-aleatórias atuaram sobre a variação da profundidade do preparo do solo. 


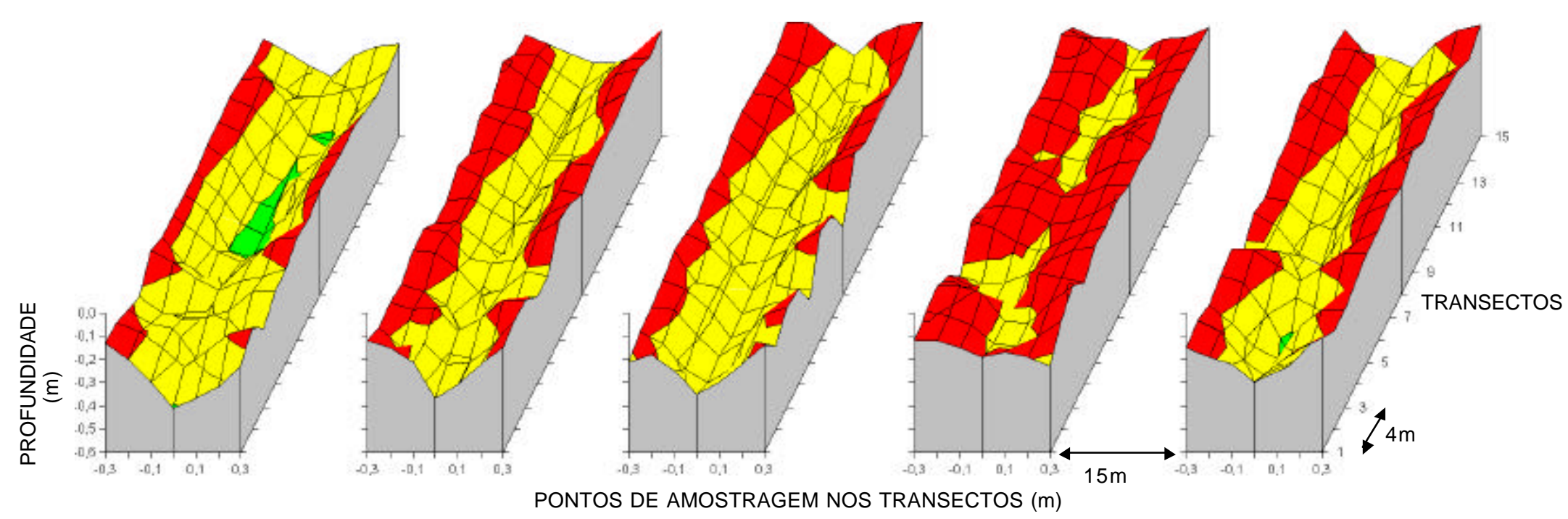

L1

L2

L3

L4

L5

Camadas de profundidade mobilizadas $(\mathrm{m})$

$\square 0,0$ a $-0,2 \quad \square-0,2$ a $-0,4 \quad \square-0,4$ a - 0,6

Figura 14 -Variação média do sulco de preparo do solo em cinco linhas de trabalho (L1 a L5) e em quinze transectos consecutivos. 
PONTOS DE AMOSTRAGEM NOS TRANSECTOS (m)

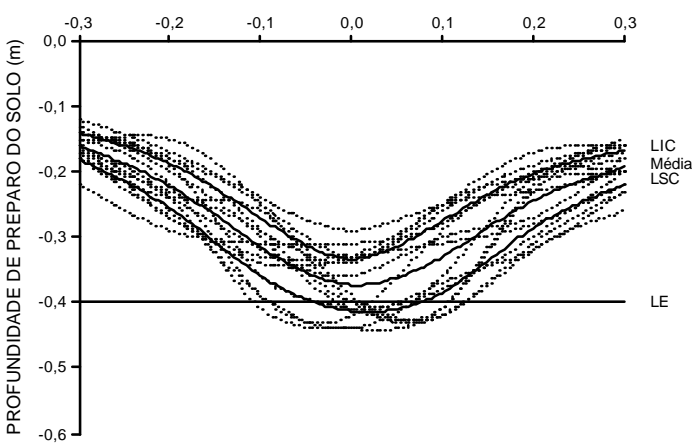

Linha de trabalho 1

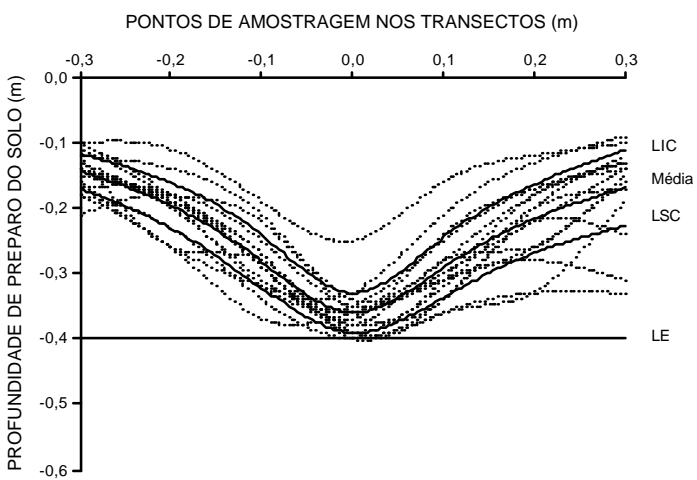

Linha de trabalho 3
PONTOS DE AMOSTRAGEM NOS TRANSECTOS (m)

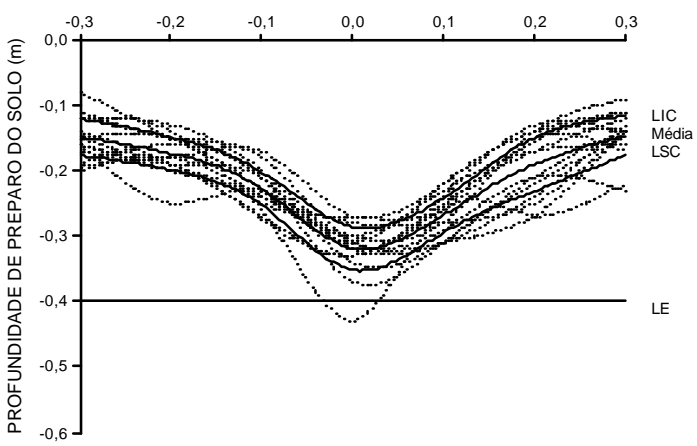

Linha de trabalho 2

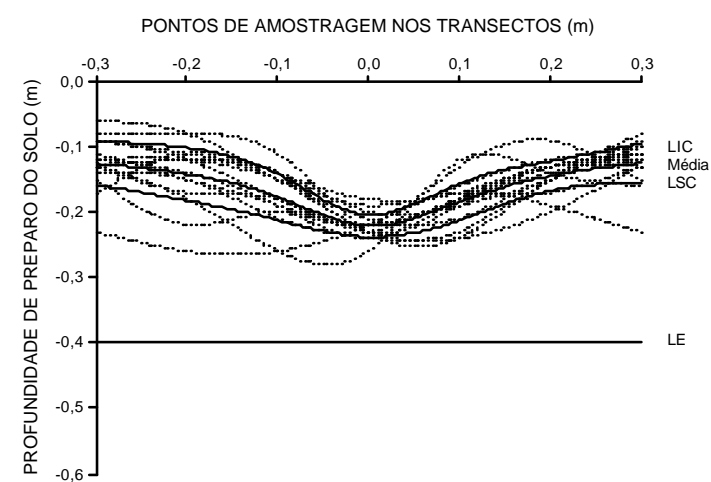

Linha de trabalho 4

PONTOS DE AMOSTRAGEM NOS TRANSECTOS (m)

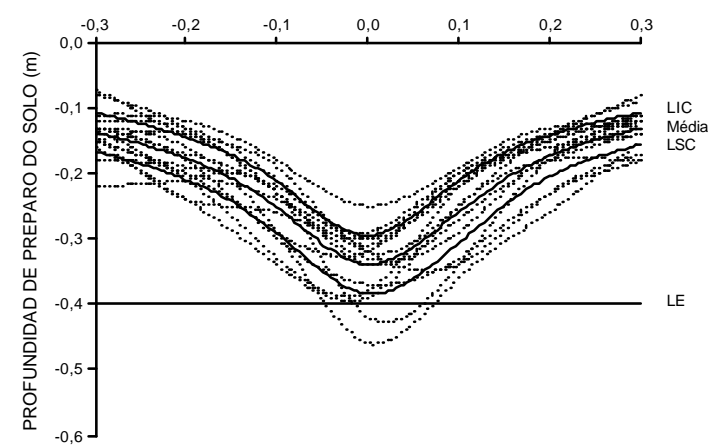

Linha de trabalho 5

Figura 15 - Gráficos de controle da média para a profundidade do sulco de preparo do solo (LIC = Limite Inferior de Controle; LSC = Limite Superior de Controle; LE = Linha de Especificação). 


\subsubsection{Diâmetro dos torrões sobre a linha central do sulco}

Na Figura 16 são apresentados os gráficos de controle da média e da amplitude para o diâmetro do torrão. $\mathrm{Na}$ área do estudo, a média do diâmetro do torrão encontrada foi de $0,027 \mathrm{~m}$, variando entre $0,018 \mathrm{~m}$ e 0,034 $\mathrm{m}$. Analisando-se o gráfico da média (Figura 16a), observourse que os valores apresentaram distribuição dentro dos limites de controle. Entretanto, no gráfico da amplitude (Figura 16b), verificou-se a existência de pontos fora do limite superior (amostras 16 e 17), o que caracterizou a falta de controle para a variável analisada. Isso significou que causas não-aleatórias atuaram sobre a variação do diâmetro do torrão.

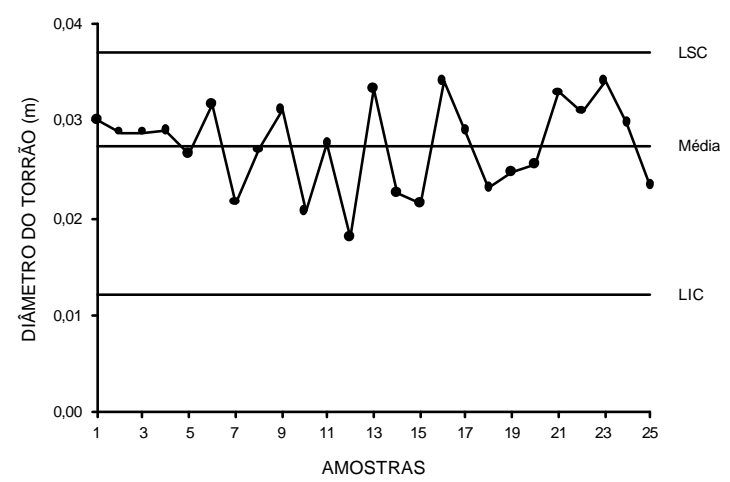

(a)

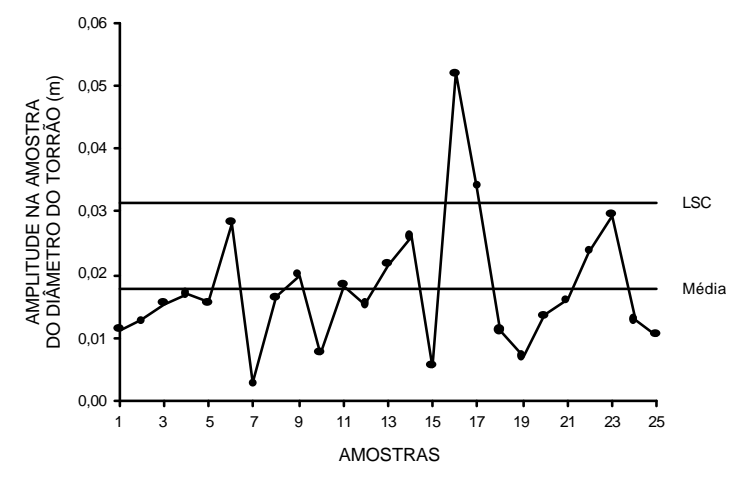

(b)

Figura 16 - Gráficos de controle para o diâmetro do torrão: a) média; b) amplitude (LSC = Limite Superior de Controle; LIC = Limite Inferior de Controle).

\subsubsection{Volume cilíndrico dos galhos de madeira sobre a faixa de sulcamento}

Na Figura 17 são apresentados os gráficos de controle da média e da amplitude para o volume cilíndrico dos galhos. Na área do estudo, a média 
do volume cilíndrico dos galhos encontrada foi de $12,53 \mathrm{~cm}^{3} \mathrm{~m}^{-2}$, variando entre $1,30 \mathrm{~cm}^{3} \mathrm{~m}^{-2}$ e $41,10 \mathrm{~cm}^{3} \mathrm{~m}^{-2}$. Analisando-se o gráfico da média (Figura 17a) observou-se que os valores apresentaram distribuição dentro dos limites de controle. No gráfico da amplitude (Figura 17b), observourse a presença de dois pontos fora do limite superior (amostras 17 e 20), o que caracterizou a falta de controle para a variável analisada. Isso significou que causas não-aleatórias atuaram sobre a variação do volume cilíndrico dos galhos.

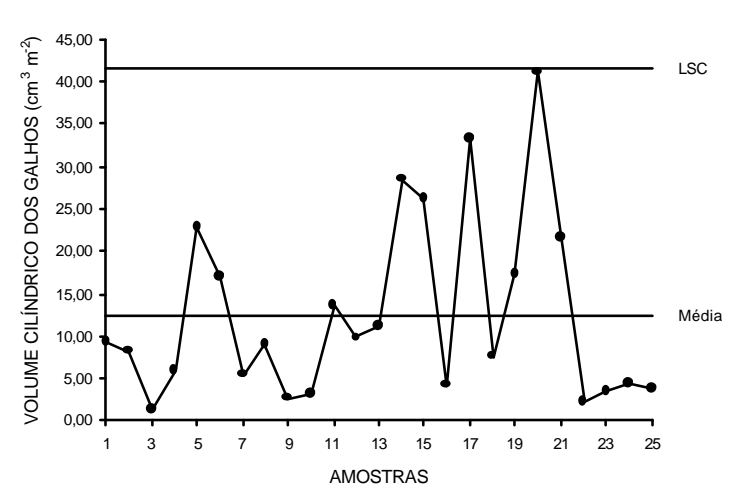

(a)

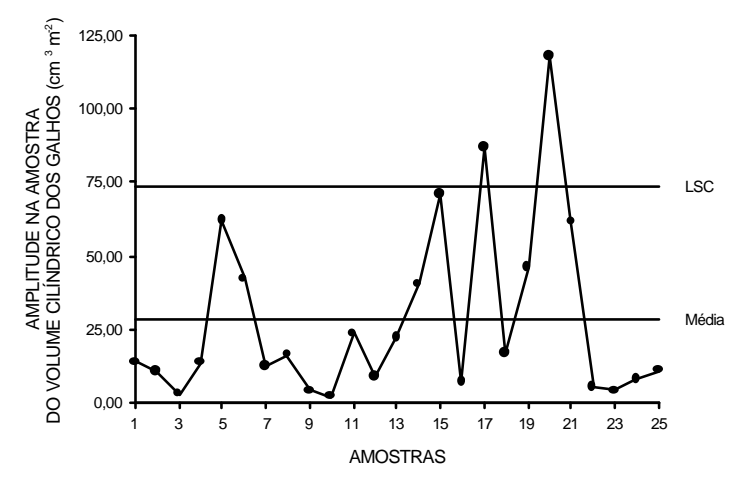

(b)

Figura 17 - Gráficos de controle para o volume cilíndrico dos galhos: a) média; b) amplitude (LSC = Limite Superior de Controle).

\subsubsection{Análise conjunta dos itens de verificação do preparo do solo}

A análise conjunta dos resultados encontrados para a profundidade do preparo do solo, o diâmetro do torrão e o volume cilíndrico dos galhos, permitiu afirmar que a operação de preparo mecanizado do solo não está sob controle estatístico na área do estudo. As causas não-aleatórias responsáveis pela variação da operação fora dos limites de controle, entretanto, não são sistemáticas e poderiam ser evitadas ou eliminadas através de treinamentos dos operadores das máquinas e regulagens dos implementos e tratores. 


\subsection{Itens de controle dos sistemas de plantio}

\subsubsection{Distância entre plantas}

No sistema manual, a média da distância entre plantas foi de 2,15 $\mathrm{m}$, variando entre $1,50 \mathrm{~m}$ e 4,55 m. A classe que inclui a especificação da empresa (entre 2,00 m e 2,50 m, com centro de classe igual a 2,25 m) representou $77,7 \%$ dos valores encontrados (Figura 18a). No sistema mecanizado, a média da distância entre plantas foi de 2,60 $\mathrm{m}$, variando entre $1,40 \mathrm{~m}$ e $9,60 \mathrm{~m}$. A classe entre $2,00 \mathrm{~m}$ e 2,50 m representou somente $43,6 \%$ dos valores encontrados (Figura 18b).

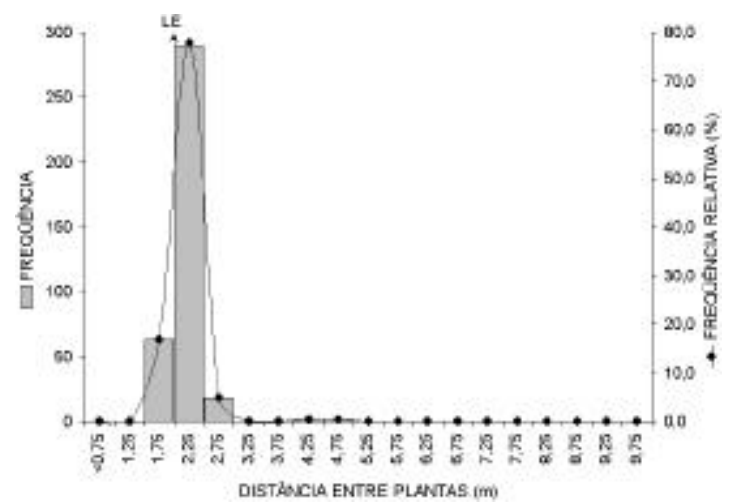

(a)

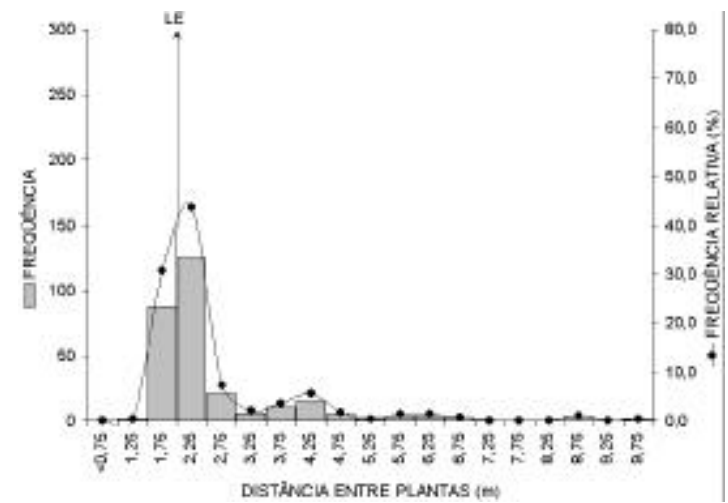

(b)

Figura 18 - Histogramas de distribuição da distância entre plantas: a) sistema manual; b) sistema mecanizado (LE = Linha de Especificação).

Comparando-se as médias da distância entre plantas, pelo teste $\mathrm{t}$ não-pareado, comprovourse a diferença dos resultados entre os sistemas de plantio (Tabela 2). 
Tabela 2. Comparação das médias da distância entre plantas, entre os sistemas de plantio, pelo teste t não-pareado.

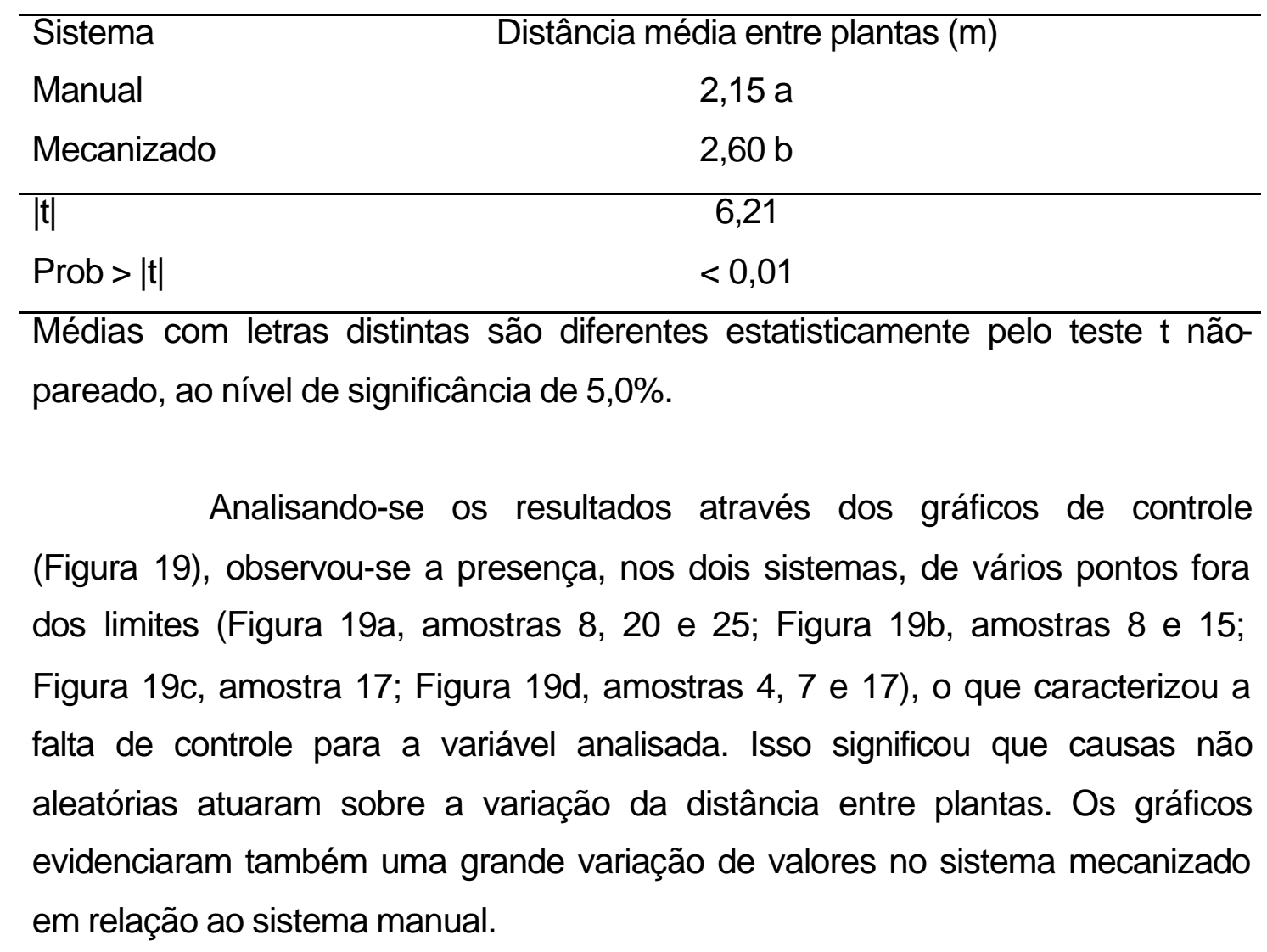




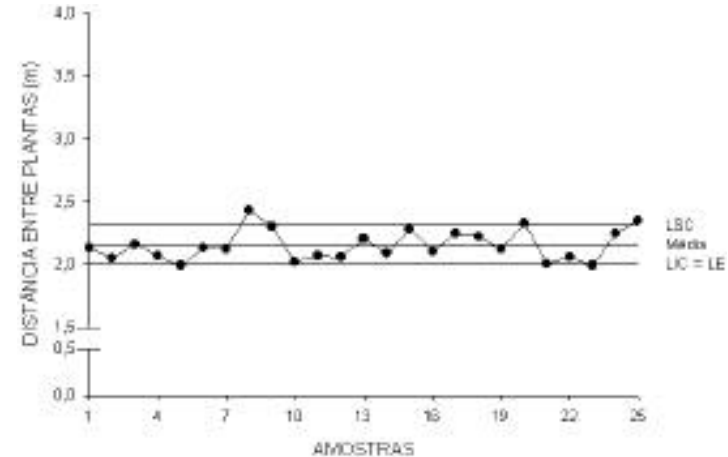

(a)

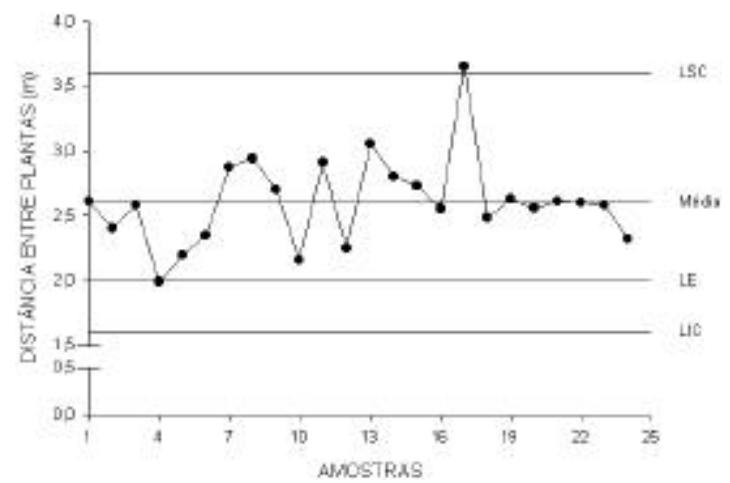

(c)

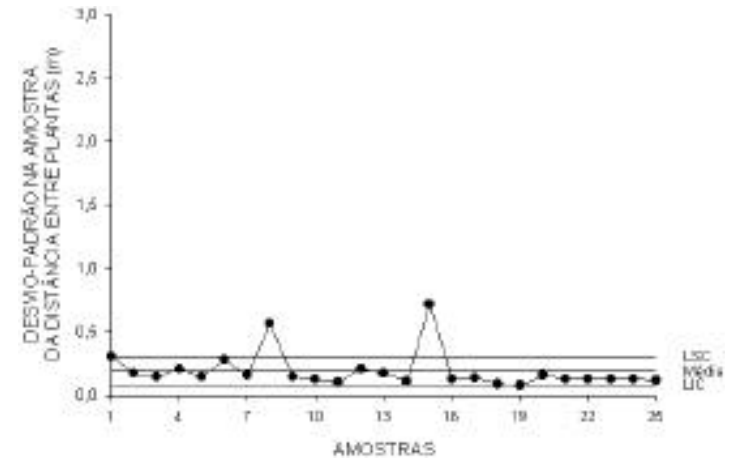

(b)

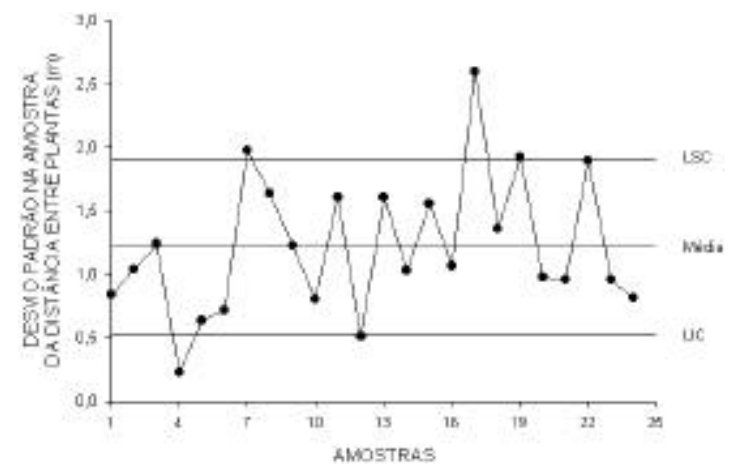

(d)

Figura 19 - Gráficos de controle para a distância entre plantas: a) média para o sistema manual; b) desvio-padrão para o sistema manual; c) média para o sistema mecanizado; d) desvio-padrão para o sistema mecanizado (LSC = Limite Superior de Controle; LIC = Limite Inferior de Controle; LE = Linha de Especificação).

Considerando-se a distância entre linhas igual a 3,00 m para os dois sistemas de plantio (especificação da empresa), estimou-se que o número médio de mudas plantadas foi igual a 1.550 plantas por hectare no plantio manual e igual a 1.282 plantas por hectare no plantio mecanizado. Isso significou que o sistema mecanizado foi $17,4 \%$ menos eficiente na distribuição correta das mudas que o sistema manual. 


\subsubsection{Defeitos do plantio}

Na Figura 20 são apresentados os gráficos de controle para o número de defeitos por muda efetivamente plantada, nos dois sistemas de plantio. A média do número de defeitos por muda no sistema manual foi de 1,74, variando entre 1,07 e 2,40. Analisando-se a Figura $20 \mathrm{a}$, observou-se uma tendência ascendente, o que caracterizou a falta de controle, apesar da não existência de valores fora do limite superior. No sistema mecanizado, a média do número de defeitos por muda foi de 1,61, variando entre 1,07 e 2,07. Analisando-se a Figura 20b, observou-se que os valores encontrados estão sob controle.

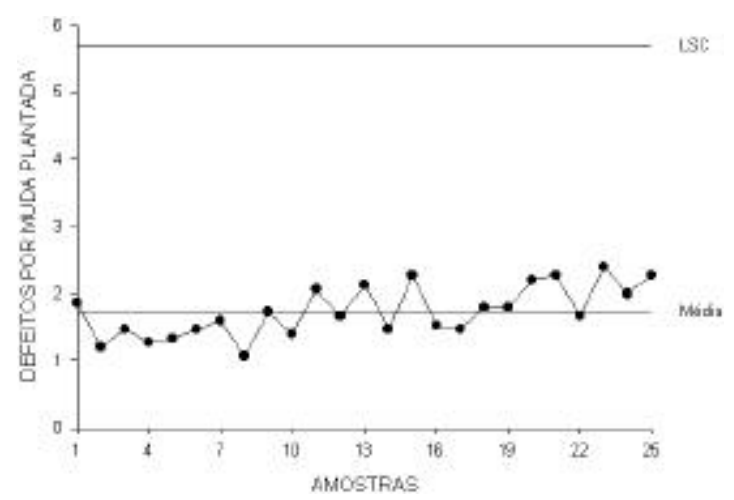

(a)

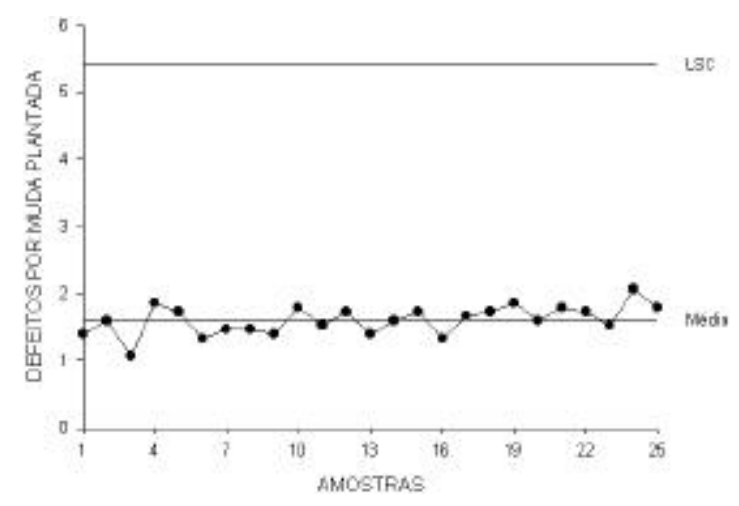

(b)

Figura 20 - Gráficos de controle do número de defeitos por muda efetivamente plantada: a) sistema manual; b) sistema mecanizado (LSC = Limite Superior de Controle).

Comparando-se as médias do número de defeitos por muda plantada, pelo teste t rão-pareado, verificou-se a semelhança dos resultados entre os sistemas (Tabela 3). 
Tabela 3. Comparação das médias do número de defeitos por muda plantada, entre os sistemas, pelo teste t não-pareado.

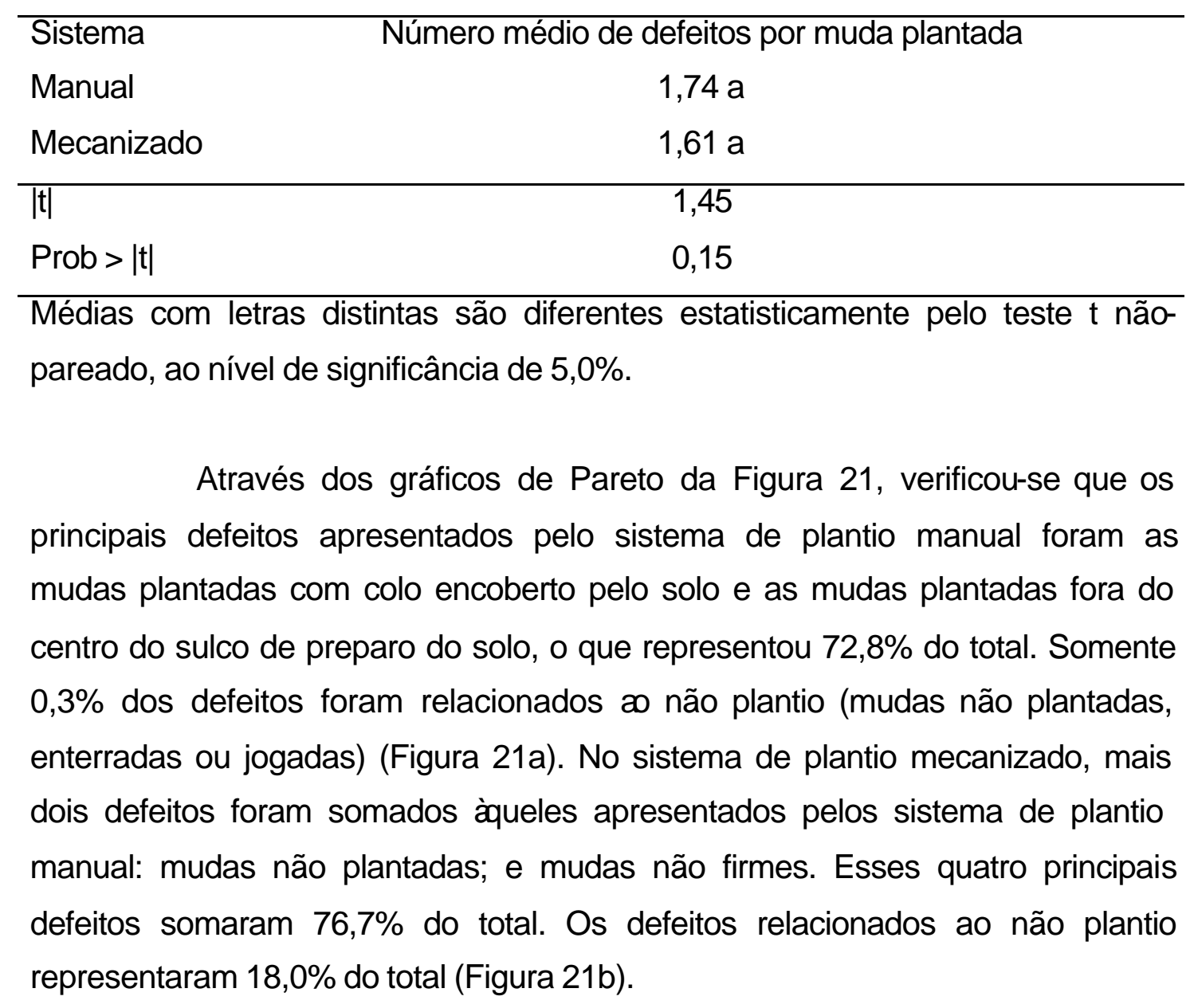




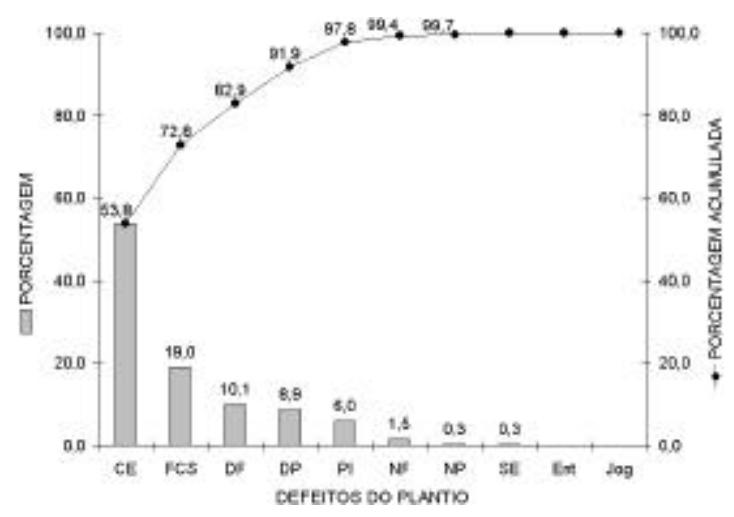

(a)

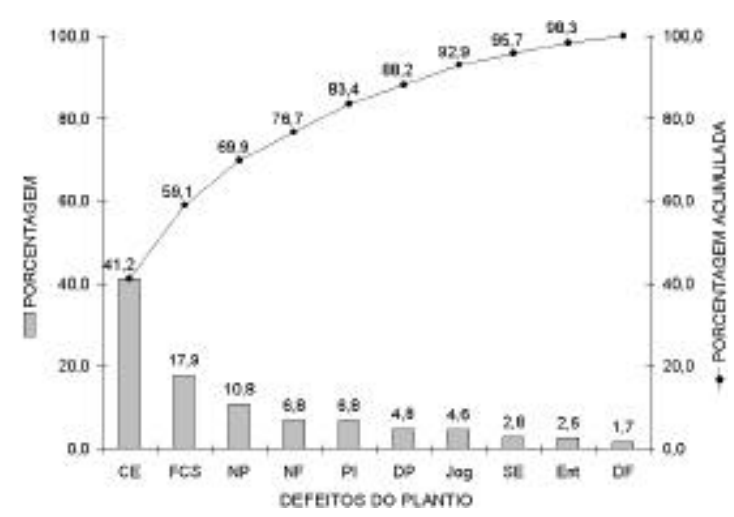

(b)

Figura 21 - Gráficos de Pareto para os defeitos do plantio: a) sistema manual; b) sistema mecanizado ( $\mathrm{CE}$ = muda com colo encoberto pelo solo; FCS = muda fora do centro do sulco; DF = muda com danos nas folhas; $\mathrm{DP}=$ muda com danos no ponteiro; $\mathrm{PI}=$ muda plantada inclinada; NF = muda não firme; NP = muda não plantada; SE = muda com substrato exposto; Ent = muda enterrada; Jog = muda jogada).

Comparando-se a presença ou ausência dos defeitos do plantio, pelo teste de qui-quadrado, verificou-se a diferença dos resultados entre os sistemas para a maioria $(80,0 \%)$ dos defeitos (Tabela 4). Somente os defeitos muda fora do centro do sulco (FCS) e muda plantada inclinada (PI) foram semelhantes, estatisticamente, entre os sistemas de plantio. 
Tabela 4. Comparação da presença ou ausência dos defeitos no plantio, entre os sistemas, pelo teste de qui-quadrado $(\mathrm{CE}=$ muda com colo encoberto pelo solo; FCS = muda fora do centro do sulco; DF = muda com danos nas folhas; $\mathrm{DP}=$ muda com danos no ponteiro; $\mathrm{PI}=$ muda plantada inclinada; NF = muda não firme; $\mathrm{NP}=$ muda não plantada; $\mathrm{SE}=$ muda com substrato exposto; Ent = muda enterrada; Jog = muda jogada).

\begin{tabular}{|c|c|c|c|c|c|c|c|c|c|c|}
\hline \multirow[b]{2}{*}{ Sistema/Defeito } & \multicolumn{10}{|c|}{ Presença dos defeitos nos sistemas de plantio (\%) } \\
\hline & CE & FCS & DF & DP & $\mathrm{PI}$ & NF & NP & SE & Ent & Jog \\
\hline Manual & $93,3 \mathrm{a}$ & $33,1 \mathrm{a}$ & $17,6 \mathrm{a}$ & $15,5 \mathrm{a}$ & $10,4 \mathrm{a}$ & $2,7 \mathrm{a}$ & $0,5 \mathrm{a}$ & $0,5 \mathrm{a}$ & $0,0 \mathrm{a}$ & $0,0 \mathrm{a}$ \\
\hline Mecanizado & $66,4 \mathrm{~b}$ & $28,8 \mathrm{a}$ & $2,7 \mathrm{~b}$ & $7,7 \mathrm{~b}$ & $10,9 \mathrm{a}$ & $10,9 \mathrm{~b}$ & $17,3 \mathrm{~b}$ & $4,5 b$ & $4,3 \mathrm{~b}$ & $7,5 \mathrm{~b}$ \\
\hline Qui-quadrado & 84,59 & 1,60 & 45,92 & 10,94 & 0,06 & 20,22 & 65,05 & 12,15 & 16,35 & 29,09 \\
\hline Prob & $<0,01$ & 0,21 & $<0,01$ & $<0,01$ & 0,81 & $<0,01$ & $<0,01$ & $<0,01$ & $<0,01$ & $<0,01$ \\
\hline
\end{tabular}

Percentagens com letras distintas, nas colunas, são diferentes estatisticamente pelo teste de qui-quadrado, ao nível de significância de 5,0\%.

\subsubsection{Crescimento inicial e sobrevivência das plantas}

$\mathrm{Na}$ Figura 22 são apresentados os histogramas de distribuição referentes àaltura inicial das mudas, para os dois sistemas de plantio. As mudas do plantio manual apresentaram altura média de 0,298 $\mathrm{m}$, variando entre $0,160 \mathrm{~m}$ e $0,400 \mathrm{~m}$. Nesse sistema, $78,1 \%$ das mudas apresentaram altura entre 0,250 m e 0,350 m (limites de especificação da empresa) (Figura 22a). As mudas do plantio mecanizado apresentaram altura média de 0,270 $\mathrm{m}$, variando entre $0,120 \mathrm{~m}$ e $0,430 \mathrm{~m}$. Nesse sistema, somente $52,2 \%$ das mudas apresentaram altura entre $0,250 \mathrm{~m}$ e $0,350 \mathrm{~m}$, o que gerou uma distribuição mais achatada em comparação ao plantio manual (Figura 22b). Dessa maneira, deve-se trabalhar para reduzir a variação em ambos os sistemas, minimizandose os valores que excedem os limites e centrando-se a média entre os limites. 


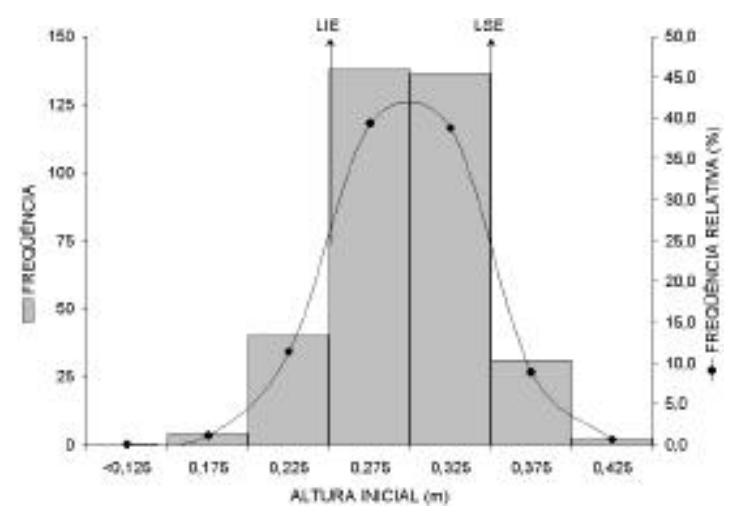

(a)

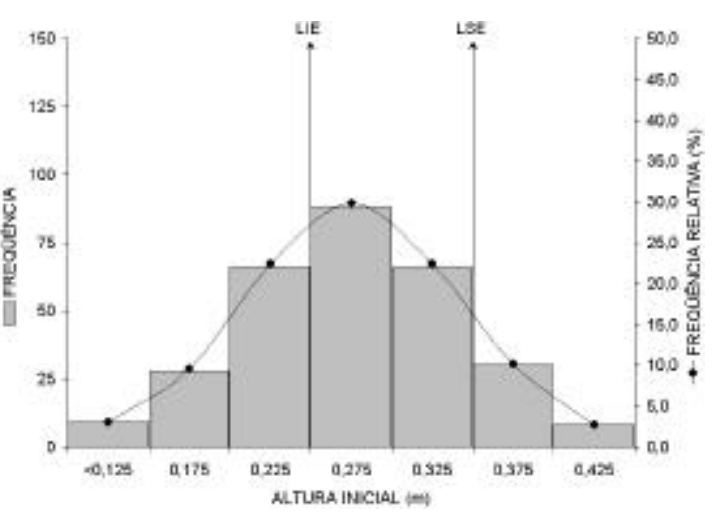

(b)

Figura 22 - Histogramas da altura inicial das mudas: a) sistema manual; b) sistema mecanizado (LIE = Limite Inferior de Especificação; LSE = Limite Superior de Especificação).

Na Figura 23 são apresentados os histogramas de distribuição referentes àaltura da parte aérea das mudas, após um mês de idade, para os dois sistemas de plantio. As mudas do plantio manual apresentaram altura média de 0,353 m, variando entre 0,245 $\mathrm{m}$ e 0,520 m (Figura 23a), com incremento de $18,5 \%$ em relação à altura inicial média. As mudas do plantio mecanizado apresentaram altura média de $0,301 \mathrm{~m}$, variando entre $0,125 \mathrm{~m}$ e $0,500 \mathrm{~m}$ (Figura 23b), com incremento de $11,5 \%$ em relação à altura inicial média. 


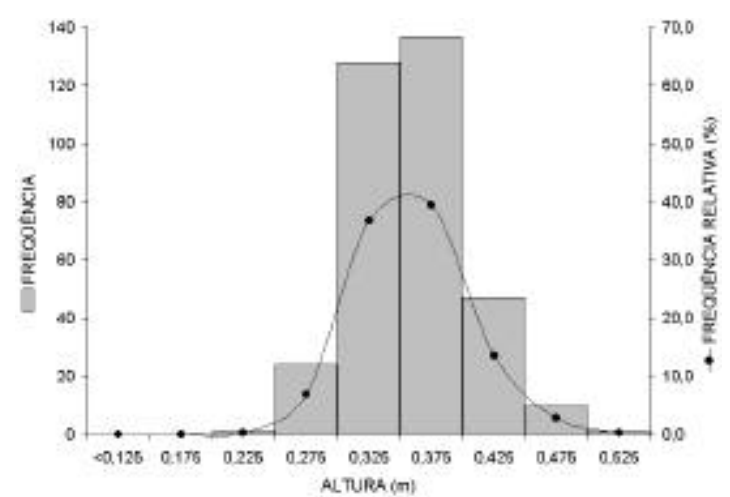

(a)

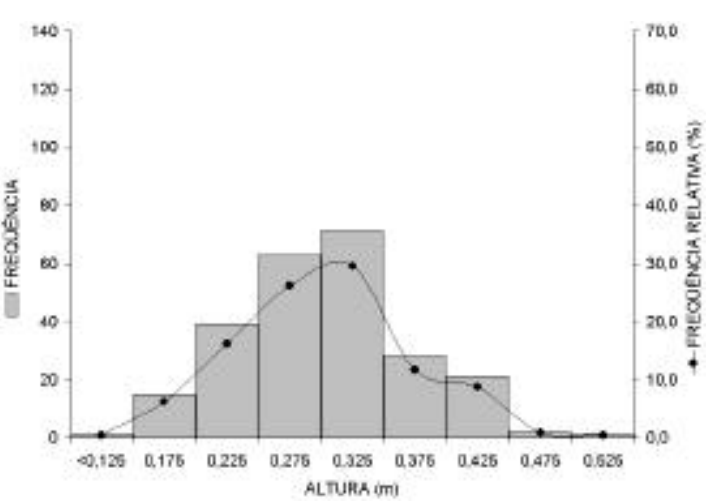

(b)

Figura 23 - Histogramas da altura da parte aérea das mudas, após um mês de idade: a) sistema manual; b) sistema mecanizado.

Comparando-se as médias da altura inicial das mudas e a altura após um mês de idade, pelo teste t não-pareado, comprovou-se a diferença dos resultados entre os sistemas (Tabela 5).

Tabela 5. Comparação das médias da altura da parte aérea das mudas inicial e após um mês de idade, entre os sistemas de plantio, pelo teste t nãopareado.

\begin{tabular}{lcc}
\hline & \multicolumn{2}{c}{ Altura da parte aérea média das mudas $(\mathrm{m})$} \\
Sistema & Inicial & Um mês após o plantio \\
Manual & $0,298 \mathrm{a}$ & $0,353 \mathrm{a}$ \\
Mecanizado & $0,270 \mathrm{~b}$ & $0,301 \mathrm{~b}$ \\
\hline$|\mathrm{t}|$ & 2,65 & 4,68 \\
Prob $>|\mathrm{t}|$ & 0,01 & $<0,01$ \\
\hline
\end{tabular}

Médias com letras distintas, nas colunas, são diferentes estatisticamente pelo teste t não-pareado, ao nível de significância de 5,0\%. 
A sobrevivência das mudas efetivamente plantadas, após um mês de idade, foi igual a $98,6 \%$ no sistema manual e a $96,7 \%$ no sistema mecanizado. Comparando-se a sobrevivência ou não das mudas, pelo teste de qui-quadrado, verificou-se a semelhança dos resultados entre os sistemas (Tabela 6).

Tabela 6. Comparação da sobrevivência ou não das mudas após um mês de idade, entre os sistemas de plantio, pelo teste de qui-quadrado.

\begin{tabular}{lc}
\hline Sistema & Sobrevivência das mudas após um mês de idade (\%) \\
Manual & $98,6 \mathrm{a}$ \\
Mecanizado & $96,7 \mathrm{a}$ \\
\hline Qui-quadrado & 2,34 \\
Prob & 0,13
\end{tabular}

Percentagens com letras distintas são diferentes estatisticamente pelo teste de qui-quadrado, ao nível de significância de 5,0\%.

\subsection{Relações de causa e efeito nos sistemas de plantio}

No sistema mecanizado, a qualidade da operação foi considerada insatisfatória e que a transplantadora mecânica deveria ser alvo de modificações para melhorar o desempenho do plantio mecanizado. Em ambos os sistemas de plantio a qualidade da operação foi prejudicada, também, pelos métodos não controlados e distância entre plantas incorreta. Essas causas, testadas neste trabalho, somadas a presença de mudas não padronizadas, ao treinamento da mão-de-obra e as condições edafo-climáticas, não testadas neste trabalho, são as principais que afetam a qualidade do processo de plantio, quer seja executado manualmente ou mecanicamente (Figura 24). 


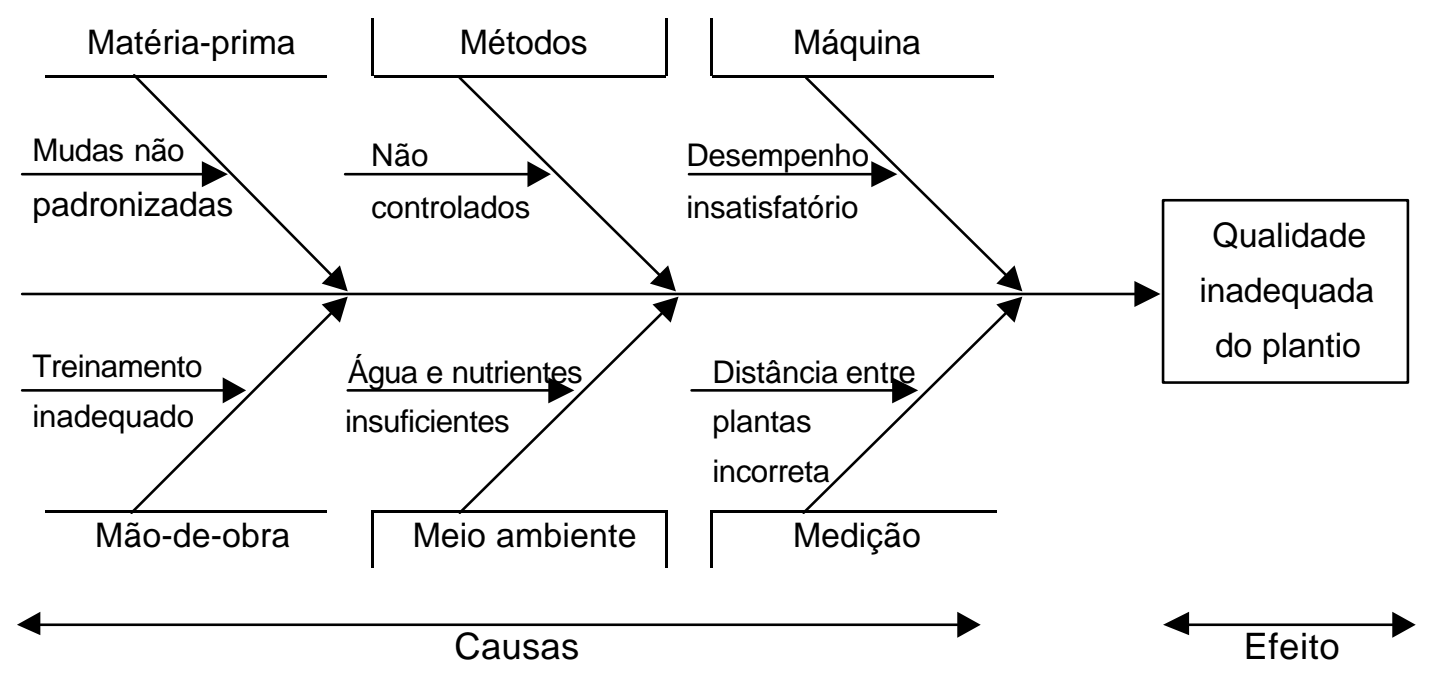

Figura 24 - Diagrama 6M aplicado a operação de plantio das mudas.

\subsection{Estimativas do desempenho e custo operacionais dos sistemas de plantio}

O número de horas disponível para o trabalho no ano foi estimado em 1.744, em uma única jornada diária de trabalho de oito horas. A capacidade de campo efetiva do sistema mecanizado foi estimada em 1,23 ha $^{-1}$, enquanto que a capacidade de campo operacional foi estimada em 0,32 ha $\mathrm{h}^{-1}$, com velocidade média de $3,65 \mathrm{~km} \mathrm{~h}^{-1}$. O tempo gasto com o carregamento das mudas representou $2,3 \%$ do tempo total, o abastecimento de água para a irrigação $8,8 \%$, as regulagens $10,0 \%$ e as manobras $30,7 \%$ do tempo total. Somente $48,2 \%$ do tempo total foi considerado produtivo (Figura 25). Isso significou que deve-se trabalhar em áreas com formato que minimizem o tempo gasto com as manobras, visando incrementar a capacidade de campo operacional do sistema mecanizado. A eliminação da irrigação realizada pela máquina pode também contribuir para a melhoria da produtividade do sistema mecanizado. 


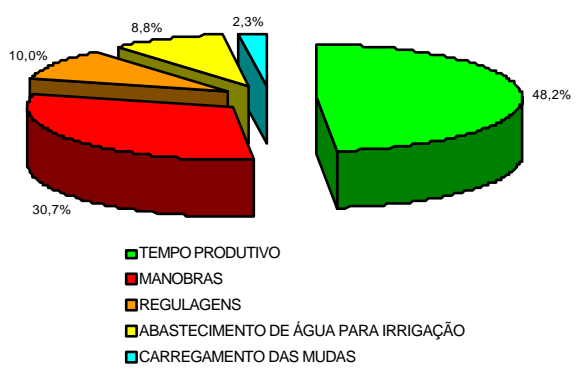

Figura 25 - Distribuição dos tempos produtivos, acessórios (manobras) e auxiliares (regulagens, abastecimento de água para irrigação e carregamento das mudas) no sistema de plantio mecanizado.

No sistema manual, a capacidade de campo operacional foi estimada em 0,80 ha $h^{-1}$, valor $60,0 \%$ superior ao encontrado no sistema mecanizado.

Considerando-se os resultados do desempenho operacional e o número médio de mudas plantadas para os dois sistemas (subdivisão 4.2.1), inferiu-se que o número médio de mudas plantadas por hora foi igual a 1.240 plantas no sistema manual (95 mudas por trabalhador por hora) e igual a 410 plantas no sistema mecanizado (205 mudas por trabalhador por hora).

Os componentes do custo horário dos sistemas de plantio são apresentados na Tabela 7. O custo horário total de cada sistema de plantio é apresentado na Tabela 8. 
Tabela 7. Composição do custo horário $\left(\mathrm{R} \$ \mathrm{~h}^{-1}\right)$ dos sistemas de plantio (ASI $=$ alojamentos, seguros e impostos; $\mathrm{RM}=$ reparos e manutenção).

\begin{tabular}{lccccc}
\hline $\begin{array}{l}\text { Componentes } \\
\text { Do custo horário }\end{array}$ & $\begin{array}{c}\text { Equipe } \\
\text { de plantio }\end{array}$ & $\begin{array}{c}\text { Trator } \\
\text { MF265 }\end{array}$ & $\begin{array}{c}\text { Carreta } \\
\text { Fachini }\end{array}$ & $\begin{array}{c}\text { Trator } \\
\text { MF290 }\end{array}$ & $\begin{array}{c}\text { Transplantadora } \\
\text { MTM-1000 }\end{array}$ \\
\hline Depreciação & - & 1,41 & 0,10 & 1,86 & 1,02 \\
Juros & - & 1,14 & 0,06 & 1,49 & 0,44 \\
ASI & - & 0,40 & 0,02 & 0,53 & 0,15 \\
RM & - & 2,94 & 0,55 & 3,86 & 6,57 \\
Combustível & - & 7,80 & - & 10,32 & - \\
Lubrificante & - & 0,17 & - & 0,21 & - \\
Trabalhadores & 32,24 & - & 2,93 & - & 2,93 \\
Líder de equipe & 3,25 & - & - & - & - \\
Operador de trator & - & 3,25 & - & 3,25 & - \\
TOTAL $\left(\mathrm{R} \$ \mathrm{~h}^{-1}\right.$ ) & 35,49 & 17,11 & 3,66 & 21,52 & 11,11 \\
\hline
\end{tabular}

Tabela 8. Custo horário total $\left(\mathrm{R} \$ \mathrm{~h}^{-1}\right)$ dos sistemas de plantio.

\begin{tabular}{lcc}
\hline Custo horário & Sistema manual & Sistema mecanizado \\
\hline Equipe de plantio & 35,49 & \\
Trator MF265 & 17,11 & \\
Carreta Fachini & 3,66 & \\
Trator MF290 & - & 21,52 \\
Transplantadora MTM-1000 & - & 11,11 \\
TOTAL $\left(\mathrm{R} \$ \mathrm{~h}^{-1}\right)$ & 56,26 & 32,63 \\
\hline
\end{tabular}

O custo horário total estimado para o sistema de plantio manual foi de $R \$ 56,26$ por hora trabalhada, enquanto que para o sistema de plantio mecanizado foi de $\mathrm{R} \$ 32,63$ por hora trabalhada. No sistema manual, o 
componente de maior peso percentual foi a mão-de-obra, que representou $74,1 \%$ do custo total horário, enquanto que o de menor peso foi o óleo lubrificante, que representou somente $0,3 \%$ do custo total horário. No sistema mecanizado, o componente de maior peso foi o de reparos e manutenção, que representou $32,0 \%$ do custo total horário, enquanto que o de menor peso foi o óleo lubrificante, que representou somente $0,6 \%$ do custo total horário. Ressalta-se, entretanto, que os custos horários com reparos e manutenção foram estimados. Os custos operacionais dos sistemas de plantio são apresentados na Tabela 9.

Tabela 9. Custo operacional $\left(\mathrm{R} \$ \mathrm{ha}^{-1}\right)$ dos sistemas de plantio.

\begin{tabular}{lcc}
\hline & $\begin{array}{c}\text { Sistema } \\
\text { Manual }\end{array}$ & $\begin{array}{c}\text { Sistema } \\
\text { mecanizado }\end{array}$ \\
\hline Custo horário total $\left(\mathrm{R} \$ \mathrm{~h}^{-1}\right)$ & 56,26 & 32,63 \\
Capacidade de campo operacional $\left(\mathrm{ha} \mathrm{h}^{-1}\right)$ & 0,80 & 0,32 \\
Custo operacional $\left(\mathrm{R} \$ \mathrm{ha}^{-1}\right)$ & 70,33 & 101,97 \\
\hline
\end{tabular}

O custo operacional estimado do sistema de plantio mecanizado foi $44,9 \%$ superior ao do sistema de plantio manual. Isso significou que o custo operacional dos sistemas serão semelhantes, para as condições do trabalho, quando a capacidade de campo operacional do sistema mecanizado for igual a 0,46 ha $^{-1}$. Neste caso o custo operacional seria igual a $R \$ 70,93$ por hectare. 


\section{CONCLUSÕES}

Considerando as condições do trabalho concluiu-se que:

- A qualidade das atividades de preparo mecanizado do solo e plantio não variaram dentro de padrões aceitáveis pela empresa florestal. Esse fato foi observado na maioria dos itens de verificação e controle das atividades de preparo do solo e plantio;

- A capacidade de campo operacional do sistema de plantio mecanizado foi inferior ao do manual. Esse fato foi devido a maior percentagem de tempo improdutivo gasto com as manobras, as regulagens e o abastecimento da máquina de transplantio de mudas. Entretanto, o número de mudas plantadas por hora por pessoa, no sistema mecanizado, foi superior em relação ao manual;

- O sistema mecanizado não realizou um plantio qualitativamente igual ao manual. Esse fato foi observado nas avaliações da distância entre plantas, dos defeitos do plantio e do crescimento inicial; e

- O custo operacional do sistema de plantio mecanizado foi superior ao do manual, para uma única jornada diária de trabalho de oito horas. Esse fato foi devido a baixa capacidade de campo operacional observada no sistema mecanizado. 


\section{ANEXOS}


Anexo A - Resultados da análise granulométrica e da análise química do solo das parcelas $(\mathrm{MO}=$ Matéria Orgânica; $\mathrm{S}=$ Soma de Bases; $\mathrm{T}=$ Capacidade de Troca Catiônica; $\mathrm{V}=$ Saturação de Bases; $\mathrm{m}=$ Saturação por $\mathrm{Al}^{3+}$ ).

Análise granulométrica

\begin{tabular}{|c|c|c|c|c|c|c|c|c|c|}
\hline \multirow{2}{*}{$\begin{array}{c}\text { Camada } \\
(\mathrm{m})\end{array}$} & \multicolumn{4}{|c|}{ Areia } & \multirow[b]{2}{*}{ Silte } & \multirow[b]{2}{*}{ Argila } & \multirow[b]{2}{*}{$D_{p}$} & \multirow[b]{2}{*}{$\mathrm{D}_{\mathrm{s}}$} & \multirow[b]{2}{*}{ Porosidade } \\
\hline & Grossa & Média & Fina & Total & & & & & \\
\hline & & & $-----\%$ & & & & $---g$ & $n^{3}---$ & $\%$ \\
\hline \multicolumn{10}{|c|}{ Parcela Sistema Manual } \\
\hline $0,0-0,2$ & 6,7 & 43,8 & 43,3 & 93,8 & 0,5 & 5,7 & 2,62 & 1,55 & 40,8 \\
\hline $0,2-0,4$ & 7,0 & 43,0 & 45,2 & 95,2 & 0,2 & 4,8 & 2,57 & 1,53 & 40,3 \\
\hline \multicolumn{10}{|c|}{ Parcela Sistema Mecanizado } \\
\hline $0,0-0,2$ & 2,7 & 32,8 & 57,0 & 92,5 & 1,8 & 5,7 & 2,62 & 1,50 & 42,7 \\
\hline $0,2-0,4$ & 2,3 & 31,0 & 60,8 & 94,2 & 0,3 & 5,5 & 2,60 & 1,48 & 42,9 \\
\hline
\end{tabular}

Análise química

\begin{tabular}{|c|c|c|c|c|c|c|c|c|c|c|c|c|}
\hline $\begin{array}{c}\text { Camada } \\
(\mathrm{m})\end{array}$ & $\mathrm{pH}$ & MO & $P$ & $\mathrm{~K}$ & $\mathrm{Ca}$ & $\mathrm{Mg}$ & $\mathrm{H}+\mathrm{Al}$ & $\mathrm{Al}$ & $S$ & $\mathrm{~T}$ & V & $\mathrm{m}$ \\
\hline & $\mathrm{CaCl}_{2}$ & $g \mathrm{dm}^{3}$ & $\mathrm{mg} \mathrm{dm}^{3}$ & & & $\mathrm{mmol}_{\mathrm{c}}$ & $\mathrm{dm}^{3}$ & & & & --- \% & \\
\hline \multicolumn{13}{|c|}{ Parcela Sistema Manual } \\
\hline $0,0-0,2$ & 4 & 17 & 7 & 0 & 4 & 1 & 50 & 13 & 5 & 68 & 7,5 & 71,8 \\
\hline $0,2-0,4$ & 4 & 16 & 6 & 0 & 3 & 1 & 47 & 13 & 4 & 64 & 6,5 & 75,7 \\
\hline \multicolumn{13}{|c|}{ Parcela Sistema Mecanizado } \\
\hline $0,0-0,2$ & 4 & 19 & 6 & 1 & 5 & 1 & 51 & 12 & 7 & 70 & 9,4 & 65,1 \\
\hline $0,2-0,4$ & 4 & 15 & 5 & 0 & 4 & 1 & 45 & 13 & 5 & 63 & 7,8 & 72,5 \\
\hline
\end{tabular}

Fonte: Laboratório de Ecologia Aplicada- LCF/ESALQ/USP. 
Anexo B - Características técnicas da transplantadora de mudas da marca Metasa, modelo MTM-1000.

\begin{tabular}{lc}
\hline Características técnicas & MTM-1000 \\
\hline Potência mínima requerida & $51,5 \mathrm{~kW}$ \\
Engate e transporte & Hidráulico/3 pontos \\
Espaçamento entre linhas & $3,0 \mathrm{~m}$ \\
Espaçamento entre plantas & $2,0 \mathrm{~m}$ \\
Capacidade de cada um dos dois reservatórios de água & $400 \mathrm{~L}$ \\
Peso da máquina & $1.020 \mathrm{~kg}$ \\
Peso de cada um dos dois reservatórios de água & $80 \mathrm{~kg}$ \\
\hline
\end{tabular}

Fonte: Fabricante da máquina. 
Anexo C - Fatores de ajuste àdistribuição normal para a estimativa dos limites de controle. Os valores em negrito foram os usados no trabalho $\left(\mathrm{c}_{2}=\right.$ fator para o gráfico de controle da média; $c_{3}$ e $c_{4}=$ fatores para 0 gráfico de controle do desvio-padrão; $d_{3}$ e $d_{4}=$ fatores para 0 gráfico de controle da amplitude).

\begin{tabular}{lccccc}
\hline Tamanho da amostra $(\mathrm{n})$ & $\mathrm{C}_{2}$ & $\mathrm{C}_{3}$ & $\mathrm{C}_{4}$ & $\mathrm{~d}_{3}$ & $\mathrm{~d}_{4}$ \\
\hline 2 & 0,564 & 0,000 & 3,267 & 0,000 & 3,267 \\
3 & 0,724 & 0,000 & 2,568 & 0,000 & 2,575 \\
4 & 0,798 & 0,000 & 2,266 & 0,000 & 2,282 \\
5 & 0,841 & 0,000 & 2,089 & 0,000 & 2,115 \\
6 & 0,869 & 0,030 & 1,970 & 0,000 & 2,004 \\
7 & 0,888 & 0,118 & 1,882 & 0,076 & 1,924 \\
8 & 0,902 & 0,185 & 1,815 & 0,136 & 1,864 \\
9 & 0,914 & 0,239 & 1,761 & 0,184 & 1,816 \\
10 & 0,922 & 0,284 & 1,716 & 0,223 & 1,777 \\
11 & 0,930 & 0,321 & 1,679 & 0,256 & 1,744 \\
12 & 0,936 & 0,354 & 1,646 & 0,284 & 1,716 \\
13 & 0,941 & 0,382 & 1,618 & 0,308 & 1,692 \\
14 & 0,945 & 0,406 & 1,594 & 0,329 & 1,671 \\
$\mathbf{1 5}$ & $\mathbf{0 , 9 4 9}$ & $\mathbf{0 , 4 2 8}$ & $\mathbf{1 , 5 7 2}$ & $\mathbf{0 , 3 4 8}$ & $\mathbf{1 , 6 5 2}$ \\
\hline
\end{tabular}

Fonte: Paladini (1990). 
Anexo D - Fatores da ASAE usados para a estimativa do custo operacional das máquinas $\left(F_{\mathrm{cpa}}=\right.$ fator da correção da depreciação para o primeiro ano; $F_{d a}=$ fator da depreciação anual; $h=$ horas de uso da máquina até a depreciação; RF1 e RF2 = fatores dos reparos e da manutenção).

\begin{tabular}{lccccc}
\hline Máquinas & $\mathrm{F}_{\mathrm{cpa}^{1}}$ & $\mathrm{~F}_{\mathrm{da}}{ }^{1}$ & $\mathrm{~h}^{2}$ & $\mathrm{RF}^{2}$ & $\mathrm{RF}^{2}$ \\
\hline Trator de pneus 4 x 2 MF265 & 0,680 & 0,920 & 12.000 & 0,007 & 2,0 \\
Carreta Fachini & 0,600 & 0,885 & 3.000 & 0,190 & 1,3 \\
Trator de pneus 4 x 2 MF290 & 0,680 & 0,920 & 12.000 & 0,007 & 2,0 \\
Transplantadora MTM-1000 & 0,600 & 0,885 & 1.500 & 0,320 & 2,1 \\
\hline
\end{tabular}

Fonte: ${ }^{1}$ ASAE, citado por Witney (1988); ${ }^{2}$ ASAE (2001d). 
ANEXOE - Preços de compra das máquinas novas $\left(V_{n}\right)$ e vidas úteis $\left(V_{u}\right)$ considerados na estimativa dos custos dos sistemas de plantio.

\begin{tabular}{lcc}
\hline Máquinas & $\mathrm{V}_{\mathrm{n}}(\mathrm{R} \$)$ & $\mathrm{V}_{\mathrm{u}}(\text { anos })^{2}$ \\
\hline Trator de pneus 4 x 2 MF265 & $35.000,00^{1}$ & 10 \\
Carreta Fachini & $2.090,00^{2}$ & 10 \\
Trator de pneus 4 x 2 MF290 & $46.000,00^{1}$ & 10 \\
Transplantadora MTM-1000 & $13.150,00^{2}$ & 5 \\
\hline
\end{tabular}

Fonte: ${ }^{1}$ Silveira (2002); ${ }^{2}$ Fabricantes das máquinas. 
ANEXO F - Salários mensais da mão-de-obra considerados na estimativa dos custos dos sistemas de plantio.

\begin{tabular}{lc}
\hline Mão-de-obra & Salários mensais $(\mathrm{R} \$)$ \\
\hline Operador de trator & 236,00 \\
Líder de equipe & 236,00 \\
Trabalhador rural & 213,00 \\
\hline
\end{tabular}

Fonte: Empresa prestadora de serviços florestais. 


\section{REFERÊNCIAS BIBLIOGRÁFICAS}

ALMEIDA, A.R.C. Gestão operacional da qualidade: uma abordagem prática e abrangente no setor florestal. Campinas: Editora da Unicamp, 2000. 128p.

ALVES, M.I.F.; PIESKE, O.R. Controle estatístico de qualidade utilizando o Excel. Piracicaba: ESALQ, Departamento de Matemática e Estatística, 1997. 98p.

AMERICAN SOCIETY OF AGRICULTURAL ENGINEERING. ASAE standards 2001: standards, engineering practices, and data. 48. ed. St. Joseph. 2001a. p. 109-112: ASAE EP291.2 - Terminology and definitions for soil tillage and soil-tool relationships.

AMERICAN SOCIETY OF AGRICULTURAL ENGINEERING. ASAE standards 2001: standards, engineering practices, and data. 48. ed. St. Joseph. 2001b. p. 354-355: ASAE S495 - Uniform terminology for agricultural management.

AMERICAN SOCIETY OF AGRICULTURAL ENGINEERS. ASAE standards 2001: standards, engineering practices and data. 48. ed. St. Joseph. 2001c. p. 356-361: ASAE EP496.2 - Agricultural machinery management.

AMERICAN SOCIETY OF AGRICULTURAL ENGINEERS. ASAE standards 2001: standards, engineering practices, and data. 48. ed. St. Joseph. 2001d. p. 362-369: ASAE D497.4 - Agricultural machinery management data. 
APPELROTH, S.E. Planting tube makes it easy to plant japanese paperpot planting stock in Finland. The Forestry Chronicle, v.47, n.6, p.350-351, Dec. 1971.

APPELROTH, S.E. Work study aspects of planting and direct seeding in forestry. In: SYMPOSIUM STAND ESTABLISHMENT, Wageningen, 1974. Proceedings. Wageningen: IUFRO, 1974. p.202-267.

ARANDA, F.D. Forestacion mecanizada en Chile. Chile Forestal. Documento Tecnico, v.210, p.1-7, out.1993.

ASSOCIAÇÃO BRASILEIRA DE CELULOSE E PAPEL. Relatório estatístico florestal. São Paulo: Bracelpa, 2001. 60p.

BALASTREIRE, L.A. Máquinas agrícolas. São Paulo: Manole, 1990. 307p.

BALENSIEFER, M. Estudo de diferentes métodos de plantio com Pinus taeda na região de Guarapuava - Paraná. Curitiba, 1978. 100p. Dissertação (Mestrado) - Setor de Ciências Agrárias, Universidade Federal do Paraná.

BARROS, J.W.D. Planejamento da qualidade do preparo mecanizado do solo para implantação de florestas de Eucalyptus spp utilizando o método desdobramento da função qualidade (QFD). Piracicaba, 2001. 117p. Dissertação (Mestrado) - Escola Superior de Agricultura "Luiz de Queiroz", Universidade de São Paulo. 
BENTIVENHA, S.R.P.; GONÇALVES, J.L.M.; SASAKI, C.M. Mobilização do solo e crescimento inicial do eucalipto em função do tipo de haste subsoladora, profundidade de trabalho e características do solo (compact disc). In: SEMINÁRIO SOBRE MÉTODOS E EQUIPAMENTOS DE PREPARO DE SOLO PARA O PLANTIO DE FLORESTAS, Piracicaba, 2000. Resumos. Piracicaba: IPEF, 2000. p. 62-99.

BONILLA, J.A. Qualidade total na agricultura: fundamentos e aplicações. Belo Horizonte: Centro de Estudos da Qualidade Total na Agricultura, 1994. $344 p$.

BONILLA, J.A. Métodos quantitativos para a qualidade total na agricultura. Contagem: Líttera Maciel, 1995. 250p.

BORSSATO, I.; RECH, B.; FREITAS, A.J.P. Efeito do preparo de solo sobre o desenvolvimento de Eucalyptus saligna SMITH. Silvicultura, v.8, n.28, p.192-194, 1983.

BORTOLAI, R. Roteiro para cálculo de custo horário de máquinas florestais. Boletim Informativo IPEF, v.3, n.10, p.10-19, jun. 1975.

BRADY, N. C.; WEIL, R.R. The nature and properties of soils. Upper Saddle River: Prentice Hall, 1999. 881p.

BURLA, E.R. Mecanização de atividades silviculturais em relevo ondulado. Belo Oriente: Cenibra, 2001.144p. 
CAMPOS, V.F. TQC: controle de qualidade total (no estilo japonês). Belo Horizonte: Fundação Christiano Ottoni; UFMG, Escola de Engenharia, 1992. $220 p$.

CARNEIRO, J.G.A. Variações na metodologia de produção de mudas florestais afetam os parâmetros morfofisiológicos que indicam sua qualidade. Série Técnica FUPEF, n.12, p.1-40, maio 1983.

CARNEIRO, J.G.A. Produção e controle de qualidade de mudas florestais. Curitiba: UFPR; UENF; FUPEF, 1995. 451p.

CORMIER, D.; RYANS, M. Short and long-term evaluation of the Silva Nova planting machine. Feric Technical Note, n.190, p.1-16, Nov.1992.

CRAM, W.H. A mechanical planter for hardwood cuttings. Tree Planters' Notes, v.34, n.1, p.7-9, 1983.

DEDECEK, R.A.; GAVA, J.L. Compactação do solo pela colheita de eucalipto: sua avaliação e efeito na produtividade da rebrota. In: CONFERÊNCIA IUFRO SOBRE SILVICULTURA E MELHORAMENTO DE EUCALIPTOS., Salvador, 1997. Anais. Colombo: EMBRAPA, CNPF, 1997. v.3, p.63-68.

DELLARETTI FILHO, O.; DRUMOND, F.B. Itens de controle e avaliação de processos. Belo Horizonte: UFMG; Fundação Christiano Ottoni, 1994. $151 \mathrm{p}$.

EMPRESA BRASILEIRA DE PESQUISA AGROPECUÁRIA. Manual de métodos de análise de solo. 2.ed. Rio de Janeiro, 1997. 212p. 
EMPRESA BRASILEIRA DE PESQUISA AGROPECUÁRIA. Sistema brasileiro de classificação de solos. Brasília, 1999. 412p.

FAGUNDES, M.A. O plantio mecanizado em silvicultura. Silvicultura em São Paulo, v.4/5, n.4, p.181-188, 1965/1966.

FERNANDES, R.A.T. Aplicação de conceitos da qualidade em operações mecanizadas na produção de milho (Zea Mays L.) para silagem. Piracicaba, 2000. 81p. Dissertação (Mestrado) - Escola Superior de Agricultura "Luiz de Queiroz", Universidade de São Paulo.

FREITAS, M.; SILVA, A.P.; CANEVA, R.A.; BEIG, O. Avaliação e controle de qualidade em florestas de Eucalyptus. Circular Técnica IPEF, n.91, p.1-8, fev. 1980.

GAMERO, C.A.; LANÇAS, K.P. Ensaio \& certificação das máquinas de mobilização periódica do solo. In: MIALHE, L.G. (Ed.). Máquinas agrícolas: ensaios \& certificação. Piracicaba: FEALQ, 1996. cap. 9, p.463-514.

GONÇALVES, J.L.M.; STAPE, J.L.; BENEDETTI, V.; FESSEL, V.A.G.; GAVA, J.L. Reflexos do cultivo mínimo e intensivo do solo em sua fertilidade e na nutrição das árvores. In: BENEDETTI, V.; GONÇALVES, J.L.M. (Ed.). Nutrição e fertilização florestal. Piracicaba: IPEF, 2000. cap. 1, p.1-57.

GONÇALVES, N.H.; LIMA, E.B.; BANCHI, A.D.; PINTO, R.S.A.; LOPES, J.R. eficiências de uso de máquinas agrícolas. In: CONGRESSO NACIONAL DA SOCIEDADE DE TÉCNICOS AÇUCAREIROS E ALCOOLEIROS DO BRASIL, 5., Águas de São Pedro, 1993. Anais. Piracicaba: STAB, 1993. p.165-168. 
GULDIN, R.W. Machine planting costs are influenced by site characteristics and preparation practices. Washington: USDA, Forest Service, 1982. 4p. (Research Note, 287).

HOSOKAWA, R.T. Aplicação de computadores na estimativa dos custos de máquinas florestais. Floresta, v.8, n.2, p.31-32, dez. 1977a.

HOSOKAWA, R.T. Aplicação de computadores na estimativa dos custos de máquinas florestais. In: LEINERT, S. Curso de atualização sobre sistemas de exploração e transporte florestal. Curitiba: FUPEF, 1977b. p. 14-20.

HUANG, B.K. Systems engineering of precision automatic transplanting. ST. Joseph: ASAE, 1973. 19 p. (ASAE Paper, 73-104).

INSTITUTO DE PESQUISAS E ESTUDOS FLORESTAIS. Relatório anual IPEF de 1999. Piracicaba, 2000.79p.

JACOVINE, L.A.G. Gestão da qualidade na colheita de madeira em povoamentos eqüiâneos. Viçosa, 2000. 136p. Tese (D.S.) - Universidade Federal de Viçosa.

JURAN, J.M. Planejando para a qualidade. Tradução de J.M. Csillag e C. Csillag. São Paulo: Pioneira, 1990. 394p.

KUME, H. Métodos estatísticos para melhoria da qualidade. Trad. de D. I. Miyake. São Paulo: Gente, 1993.245p. 
LAFLEN J.M.; AMEMIYA, M.; HINTZ, E.A. Measuring crop residue cover. Journal of Soil \& Water Conservation, v.36, n6, p.341-343, Nov./Dec. 1981.

LANÇAS, K.P. Subsolagem ou escarificação: mobilização do solo sem muita agressão. Cultivar Máquinas, n.14, p.38-41, set./out. 2002.

LELES, P.S.S.; CARNEIRO, J.G.A.; BARROSO, D.G.; MORGADO, I.F. Qualidade de mudas de Eucalyptus spp. produzidas em blocos prensados e em tubetes. Revista Árvore, v.24, n.1, p.13-20, 2000.

LETEY, J. Relantionship between soil physical properties and crop production. Advances in Soil Science, v. 1, p.277-294, 1985.

LOPES, M.B.; LUNARDI FILHO, D.; PECHE-FILHO, A.; COELHO, J.L.D.; MILAN, M. Qualidade em operações agrícolas mecanizadas na cultura de cana-de-açúcar. STAB, v. 13, n.3, p.26-30, jav.ffev.1995.

MELLO, E.J.; MENCK, A.L.M.; ODA, S. Influência do método de produção de mudas na avaliação de progênies de Eucalyptus grandis. In: CONGRESSO FLORESTAL PANAMERICANO; CONGRESSO FLORESTAL BRASILEIRO, Curitiba, 1993. Anais. São Paulo: SBS, 1993. p.292-294.

METASA. Divisão de implementos agrícolas: MTM - transplantadora de mudas. http://www.metasa.com.br/implementos/produto_mtm.htm (08 set. 2002).

MIALHE, L.G. Manual de mecanização agrícola. São Paulo: Agronômica Ceres, 1974. 301p. 
MILAN, M. Controle de qualidade em operações agrícolas. In: CÂMARA, G.M.S. (Coord.). Soja: tecnologia da produção. Piracicaba: ESALQ, Departamento de Agricultura, 1998. p.113-120.

MOLIN, J.P.; MILAN,M. Adequação do trator ao implemento e ao tipo de solo (compact disc). In: SEMINÁRIO SOBRE MÉTODOS E EQUIPAMENTOS DE PREPARO DE SOLO PARA O PLANTIO DE FLORESTAS, Piracicaba, 2000. Resumos. Piracicaba: IPEF, 2000. p. 9-16.

OFICINA INTERNACIONAL DEL TRABAJO. Guia de seguridad e higiene en los trabajos forestales. Ginebra: Imprenta Kundig, 1968. 244 p.

OLIVEIRA, M.D.M. Custo operacional e ponto de renovação de tratores agrícolas de pneus: avaliação de uma frota. Piracicaba, 2000. 150p. Dissertação (Mestrado) - Escola Superior de Agricultura "Luiz de Queiroz", Universidade de São Paulo.

PALADINI, E.P. Controle de qualidade: uma abordagem abrangente. São Paulo: Atlas, 1990. 239p.

PASQUA, S.E. Controle de qualidade em operações agrícolas mecanizadas. In: CONSELHO NACIONAL DE DESENVOLVIMENTO CIENTíFICO E TECNOLÓGICO. Prêmio jovem cientista 1995: publicação resumida dos trabalhos vencedores. Porto Alegre: CNPq; Fundação Roberto Marinho; Grupo Gerdau, 1999. p.53-84. 
PECHE-FILHO, A.; COSTA, J.A.; FERRETI, G.; STORINO, M. Avaliação do grau de picagem de material orgânico: uma proposta de metodologia. In: CONGRESSO BRASILEIRO DE ENGENHARIA AGRÍCOLA, 23., Campinas, 1994. Resumos. Campinas: UNICAMP; SBEA, 1994. p.252.

ROCHA, F.E.C.; TSUJIMOTO, T.; MENEZES SOBRINHO, J.A. Plantadora de alho com mecanismo tipo correia dentada. Informativo Agropecuário, v.15, n.169, p.33-37, 1991.

SEIXAS, F. Compactação do solo devido àmecanização florestal: causa, efeitos e práticas de controle. Circular Técnica IPEF, n.163, p. 1-10, out. 1988a.

SEIXAS, F. Mecanização e exploração florestal. Piracicaba: ESALQ. Departamento de Ciências Florestais, 1988b. 186p.

SEIXAS, F. Efeitos físicos da colheita mecanizada de madeira sobre o solo. In: GONÇALVES, J.L.M.; STAPE, J.L. (Ed.). Conservação e cultivo de solos para plantações florestais. Piracicaba: IPEF, 2002. cap. 9, p.313-350.

SEIXAS, F.; OLIVEIRA JÚNIOR, E.D. Compactação do solo devido ao tráfego de máquinas de colheita de madeira. Scientia Forestalis, n. 60, p. 73-87, dez. 2001.

SILVEIRA, G.M. O preparo do solo: implementos corretos. Rio de Janeiro: Globo, 1988. 243p.

SILVEIRA, G.M. As máquinas de plantar: aplicadoras, distribuidoras, semeadoras, plantadoras, cultivadoras. Rio de Janeiro: Globo, 1989. 257p. 
SILVEIRA, G.M. Tabela de tratores de rodas novos - tração simples $(4 \times 2)$. http:/www.estado.estadao.com.br/suplementos/agri/2002/07/10/agri037.html (08 set. 2002).

SIMÕES, J.W. Plantio e tratos culturais: métodos, possibilidades e economicidade. Piracicaba: ESALQ, Departamento de Ciências Florestais, 1989. 20p.

SMITH, D.M. The pratice of silviculture. 7.ed. New York: John Willey, 1962. $552 p$.

SOCIEDADE BRASILEIRA DE SILVICULTURA. Estatísticas sobre o setor florestal brasileiro. http:/www.sbs.org.br/secure/estatisticas.htm (08 set. 2002).

SOUZA CRUZ. O conjunto do ano 2000. O Produtor do Fumo, n.101, p.8-9, 1999.

STJERNBERG, E. I. Tree planting machines: a review of the intermittent furrow and spot planting types. Feric Special Report, n.31, p.1-118, Oct. 1985.

STJERNBERG, E. I. A study of manual tree planting operations in central and eastern Canada. Feric Technical Report, n.79, p.1-42, Apr. 1988a.

STJERNBERG, E.I. Hand planting tools and equipment. Feric Technical Note, n.120, p.1-8, May 1988b. 
STJERNBERG, E.I. Planter productivity in prepared and unprepared ground: a case study. Feric Technical Note, n.162, p.1-6, Aug. 1991.

STJERNBERG, E.I. Allegro SP1200 intermittent tree planter. Feric Field Note, v.39, p.1 -2, Mar.1992.

STOLF, R. Teoria e teste experimental de fórmulas de transformação dos dados de penetrômetro de impacto em resistência do solo. Revista Brasileira de Ciências do Solo, v.15, p.229-235, 1991.

STOLF, R.; FERNANDES, J.; FURLANI-NETO, V.L. Recomendação para uso do penetrômetro de impacto modelo IAA/Planalsucar-Stolf. STAB. Açúcar, Álcool \& Subprodutos, v. 1, n. 3, p.18-23, jan./fev. 1983.

STOHR, G.W.D. Cálculo de custos de máquinas florestais. Floresta, v.8, n.2, p.23-30, dez. 1977a.

STOHR, G.W.D. Cálculo de custos de máquinas florestais. In: LEINERT, S. Curso de atualização sobre sistemas de exploração e transporte florestal. Curitiba: FUPEF, 1977b. p. 1-13.

STRAKA, T.J.; DUBOIS, M.R.; WATSON, W.F. Costs and cost component trends of hand and machine tree planting in the southern United States (1952 to 1990). Tree Planters' Notes, v.43, n.3, p.89-92, 1992.

SUITER FILHO, W.; REZENDE, G.C.; MENDES, C.J.; CASTRO, P.F. Efeitos de diversos métodos de preparo de solo sobre 0 desenvolvimento de Eucalyptus grandis HILL (EX. MAIDEN) plantado em solos com camadas de impedimento. Circular Técnica IPEF, n.90, p. 1-9, fev. 1980. 
TRENK, F.B. Evolution of modern tree planting machines. Journal of Forestry, v.61, n.10, p.726-730, Oct. 1963.

TRINDADE, C. Desenvolvimento de um sistema de controle de qualidade para a atividade florestal. Viçosa, 1993. 164p. Dissertação (M.S.) - Universidade Federal de Viçosa.

TRINDADE, C.; REZENDE, J.L.P.; JACOVINE, L.A.G.; SARTORIO, M.L. Ferramentas da qualidade: aplicação na atividade florestal. Viçosa: Universidade Federal de Viçosa, 2000. 124p.

WITNEY, B. Choosing and using farm machines. Edinburgh: Land Technology, 1988. 412p. 